\title{
Estrogen alpha receptor antagonists for the treatment of breast cancer: a review
}

\author{
Deepika Sharma, Sanjiv Kumar and Balasubramanian Narasimhan * (1)
}

\begin{abstract}
Background: Cancer is at present one of the leading causes of death in the world. It accounts for $13 \%$ of deaths occurred worldwide and is continuously rising, with an estimated million of deaths up to 2030. Due to poor availability of prevention, diagnosis and treatment of breast cancer, the rate of mortality is at alarming level globally. In women, hormone-dependent estrogen receptor positive (ER+) breast cancer making up approximately $75 \%$ of all breast cancers. Hence, it has drawn the extensive attention of researchers towards the development of effective drugs for the treatment of hormone-dependent breast cancer. Estrogen, a female sex hormone has a vital role in the initiation and progression of breast malignancy. Therefore, estrogen receptor is the central target for the treatment of breast cancer.

Conclusion: In this review, we have studied various classes of antiestrogens that have been designed and synthesized with selective binding for estrogen alpha receptor (ER). Since estrogen receptor $a$ is mainly responsible for the breast cancer initiation and progression, therefore there is need of promising strategies for the design and synthesis of new therapeutic ligands which selectively bind to estrogen alpha receptor and inhibit estrogen dependent proliferative activity.
\end{abstract}

Keywords: Estrogen receptor alpha, Antiestrogens, Relative binding affinity, Molecular docking, Breast cancer

\section{Background}

\section{Global scenario of breast cancer}

According to breast cancer statistics obtained from the global cancer project (GLOBOCAN, 2012), it was observed that 5,21,907 approx deaths cases recorded worldwide in 2012 were due to breast cancer. With the increase in age, the risk for breast cancer and death rates due to it generally increases [1]. The highest incidence of breast cancer was in Northern America and Oceania and the lowest incidence in Asia and Africa. In non-Hispanic white (NHW) and non-Hispanic black (NHB) women the frequency of occurrence and death due to breast cancer are higher than other racial groups. Global differences in the rates of breast cancer are affected by changes in risk factors prevalence and poor diagnosis of it. Adaptation of western lifestyle $[2,3]$ and delayed childbearing $[4$,

*Correspondence: naru2000us@yahoo.com

Faculty of Pharmaceutical Sciences, Maharshi Dayanand University, Rohtak, Haryana 124001, India
5] has increased the risk of breast cancer among Asian and Asian American women [2]. The extent of events of breast cancer increases among Hispanic and Hispanic American women especially due to delayed childbearing [2]. In contrast, African countries show approximately $8 \%$ new cases of breast cancer; most of the deaths occur due to the limited treatment and late stage diagnosis. According to World Health Organization (WHO 2015) reports, the highest incidence rates of breast cancer were recorded in Malaysia and Thailand [6]. In light of above, in the present review we have covered the role of estrogen receptor $\alpha$ antagonists as anticancer agents against breast cancer especially over the past decade as there was no such extensive report is found in the literature.

\section{Role of estrogen alpha in breast cancer}

Estrogen, a female sex hormone, related physiological functions are exhibited mostly by the estrogen receptors subtypes' ER- $\alpha$ and $\beta$. The estrogen receptor alpha has leading role in uterus and the mammary gland. 
Aromatase enzyme synthesizes $17 \beta$-estradiol from andostenindione. This synthesized estradiol (E2) binds to the estrogen receptor which is located in the cytoplasm undergoes receptor dimerization and this estradiol-ER complex translocated into the nucleus where this complex further bind to DNA at specific binding sites (estrogen response element). In response to estradiol hormone binding, multiprotein complexes having coregulators assemble and activate ER - mediated transcriptional activity via ER designated activation functions AF1 and AF2 to carry out the estrogenic effects. The deregulation in the functioning of these various coregulators such as alteration in concentration of coregulators or genetic dysfunctionality leads to uncontrolled cellular proliferation which results into breast cancer. Such as loss of the epithelial adhesion molecule Ecadherin leads to metastasis by disrupting intercellular contacts. Deregulation of MTA1 coregulator, enhances transcriptional repression of ER, resulting in metastasis. The AIB1 (ER $\alpha$ coregulator) get amplified, results in the activation of PEA3-mediated matrix metalloproteinase 2 (MMP2) and MMP9 expression which cause metastatic progression. Another ER coregulator SRC-1, has promoted breast cancer invasiveness and metastasis by coactivating PEA3-mediated Twist expression. In recent study, PELP1 overexpression results into ER $\alpha$ - positive metastasis. Collectively, these studies showed that ER $\alpha$ coregulators modified expression of genes involved in metastasis $[7,8]$.

\section{Mechanism of action of estrogen alpha receptor antagonists}

Endocrine therapy is first choice treatment for the most of the ER+ve breast cancer patients. Currently, three classes of endocrine therapies are widely used.

- Aromatase inhibitors (AIs): Letrozole and anastrozole decrease the estrogen production by inhibiting the aromatase enzyme thus suppressing the circulating level of estrogen [8].

- Selective estrogen receptor down regulators (SERDs): Fulvestrant, competitively inhibits estradiol binding to the ER, with greater binding affinity than estradiol. Fulvestrant-ER binding impairs receptor dimerisation, and energy-dependent nucleo-cytoplasmic shuttling, thus blocking nuclear localisation of the receptor [9].

- Selective estrogen modulator: Tamoxifen competitively bind with the estrogen receptor and displaces estrogen and thus inhibits estrogen function in breast cells. The co-activators are not binding but, inhibiting the activation of genes that enhance cell proliferation [8]. The flow diagram of role of estrogen receptor and estrogen receptor antagonist is as shown in Fig. 1.
Efforts have been aided for estrogen receptor subtype-selectivity by making changes in the structural configuration of estrogen receptors to develop specific ER- pharmacophore models. The newly developed antiestrogens should not only have good binding affinity with particular receptor but it also must have selective activation for that receptor which expressed in breast cancer progression. Therefore, selective ER $\alpha$ antagonists may be helpful for the breast cancer treatment [10].

\section{Rationale of study}

Currently, a number of breast cancer drugs are available in Fig. 2 [11, 12] namely: tamoxifen (i), raloxifene (ii), toremifene (iii) and fulvestrant (iv) but they have following limitations:

I. Tamoxifen is the drug of choice to treat patients with estrogen related (ER) breast tumors. Resistance to tamoxifen develops after some years of treatment due to change in its biocharacter from antagonist to agonist and it is also responsible for the genesis of endometrial cancer [9].

II. Women who take toremifene for a longer period to treat breast cancer are at higher risk of development of endometrial cancer.

III. Raloxifene an oral selective estrogen receptor modulator increases the incidence of blood clots, deep thrombosis and pulmonary embolism when taken by breast cancer patients.

IV. Fulvestrant down regulates the ER $\alpha$ but it has poor pharmacokinetic properties i.e. low solubility in water.

\section{Various heterocyclic analogues as estrogen alpha receptor antagonists \\ Dibenzo[b, $f]$ thiepines analogues}

Ansari et al. [13], developed some molecules of dibenzo $[b, f]$ thiepine and evaluated their antiproliferative potential against ER + ve (MCF-7) cancer cell line using MTT assay. Among synthesized derivatives, compound 1, (Fig. 3)] exhibited the potent anticancer activity with $\mathrm{IC}_{50}$ value $1.33 \mu \mathrm{M}$ against MCF-7 tumor cell line, due to arrest in G0/G1phase of cell cycle. Molecular docking studies carried out by MGL Tools 1.5.4 revealed that the tricyclic core of the compound 1 occupied the same binding space in the ER- $\alpha$ pocket as tamoxifen. The most active compound $\mathbf{1}$ showed significant homology with tamoxifen while interacting with amino acids (GLY390, ILE386, LEU387, LEU391, LEU403, GLU353, LYS449 and ILE326) of ER- $\alpha$ but the basic side chain ( $3^{\circ}$ amino alkoxy) orientated opposite 


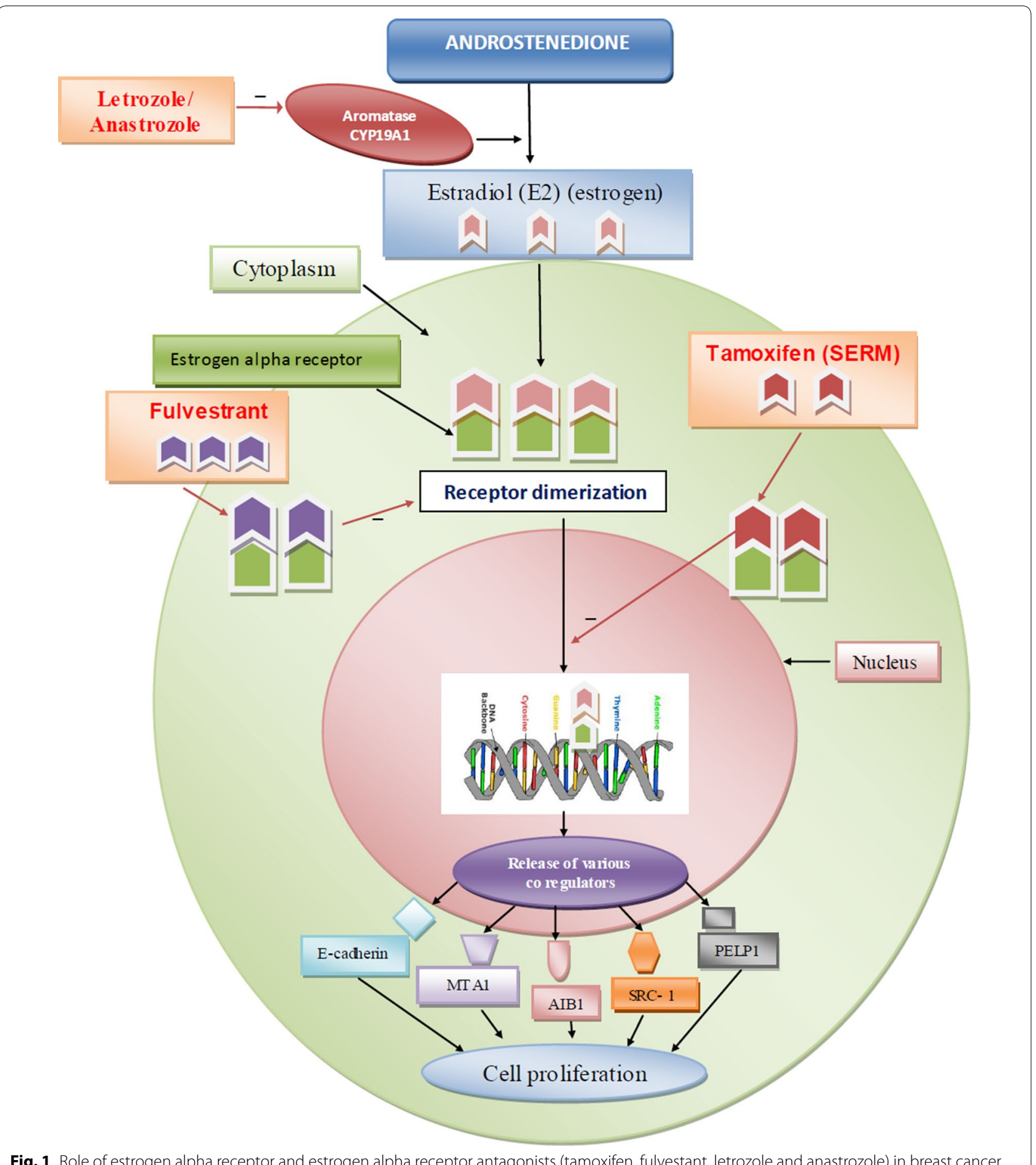

Fig. 1 Role of estrogen alpha receptor and estrogen alpha receptor antagonists (tamoxifen, fulvestant, letrozole and anastrozole) in breast cancer 
<smiles>CCC(=C(c1ccccc1)c1ccc(OCCN(C)C)cc1)c1ccccc1</smiles>

i<smiles>CN(C)CCOc1ccc(C(=C(CCCl)c2ccccc2)c2ccccc2)cc1</smiles>

iii

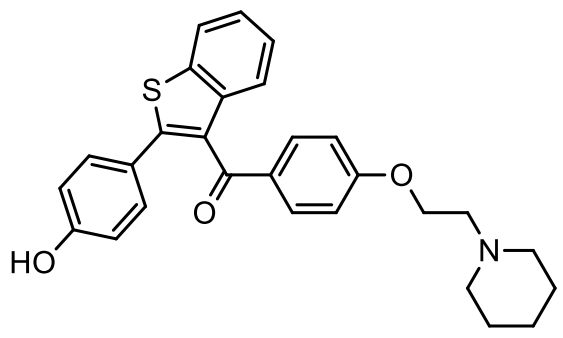

ii

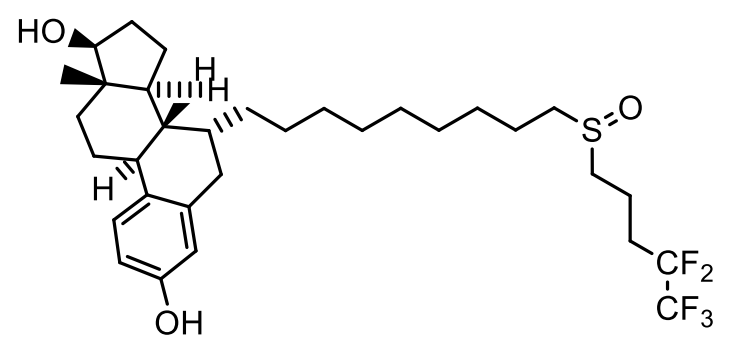

iv

Fig. 2 Marketed drugs for breast cancer<smiles>C1=C(c2ccc(OCCN3CCCCC3)cc2)c2ccccc2Sc2ccccc21</smiles>

1<smiles>CCC(=C(c1ccc(N)cc1)c1ccc(N)cc1)c1ccc([N+](=O)[O-])cc1</smiles>

8<smiles>CCCC(C)(c1ccc(O)c(C)c1)c1ccc(O)c(C)c1</smiles>

2

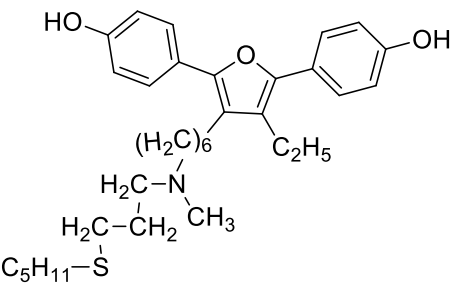

9

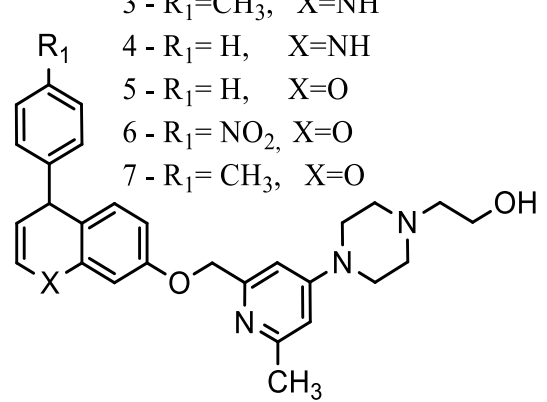

(3-7)<smiles>COc1cc2occ(C(=O)c3cccc(NC(C)=O)c3)c2cc1O</smiles>

10

Fig. 3 Molecular structures of compounds (1-10)

to that of tamoxifen (Fig. 4). Thus, it showed that compound 1 exhibited the better binding affinity with ER alpha as compared to tamoxifen $(9.6 \pm 2.2 \mu \mathrm{M})$ and this improved binding might be responsible for good antiestrogenic potential.

\section{Diphenylmethane skelon}

Maruyama et al. [14], synthesized some derivatives of diphenylmethane as estrogen antagonist that would bind to the estrogen receptor similar as estradiol. The antagonistic activity of synthesized derivatives was 


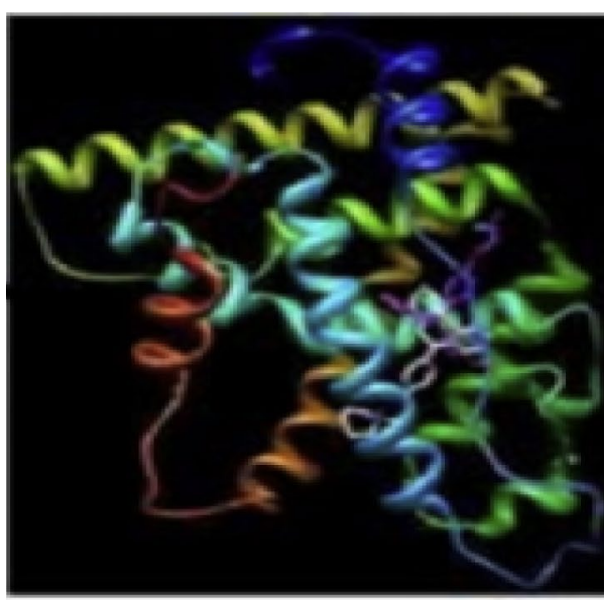

With backone

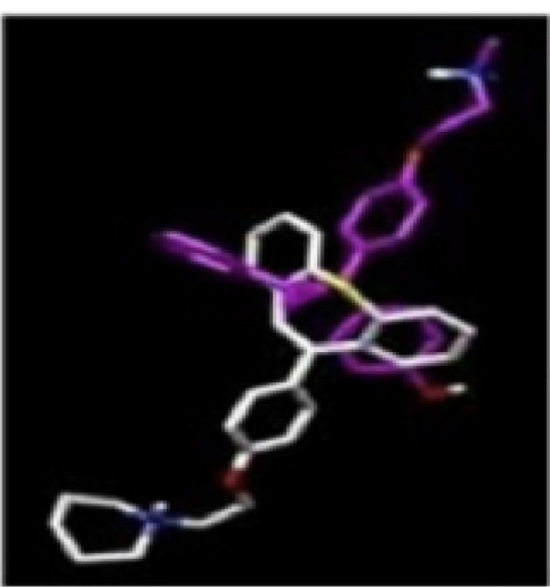

Without backone

Interaction of compound $\mathbf{1}$ with ER alpha

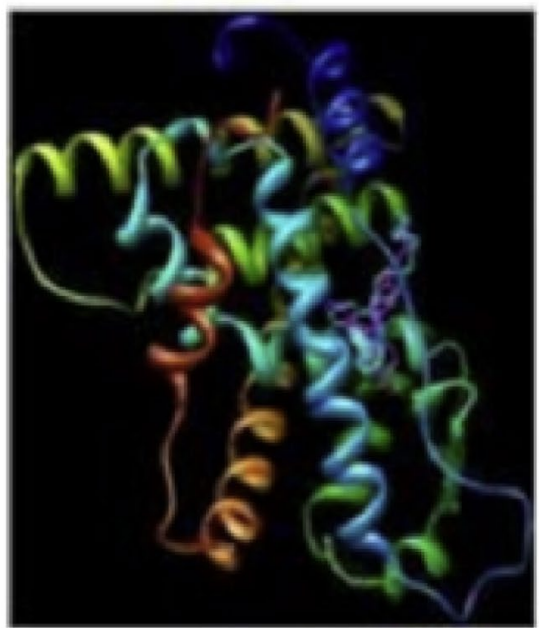

With backone

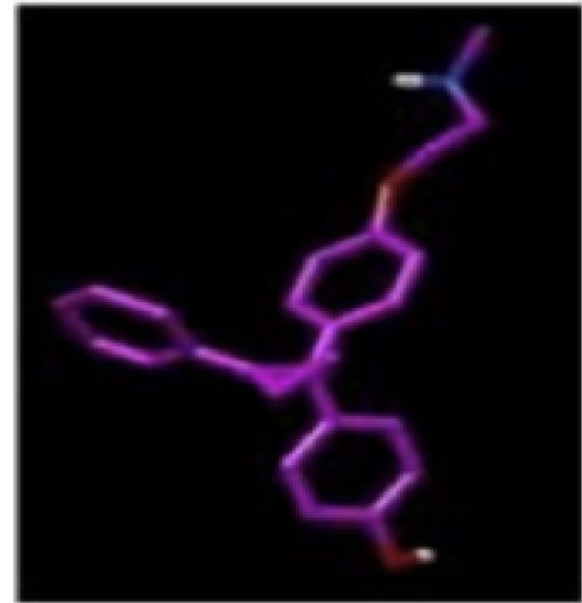

Without backone

Interaction of tamoxifen with ER alpha

Fig. 4 Pictorial presentation of interaction of compound $\mathbf{1}$ and tamoxifen with ER alpha

evaluated by AR reporter gene assay. Among the synthesized compounds, compound 2, [4,4'-(heptane4,4-diyl)bis(2-methylphenol) (Fig. 3)] was found to be potent one and displayed 28-times more selectivity for estrogen receptor alpha $\left(\mathrm{IC}_{50}=4.9 \mathrm{nM}\right)$ over estrogen receptor beta $\left(\mathrm{IC}_{50}=140 \mathrm{nM}\right)$. The binding interactions of compound $\mathbf{2}$ were determined computationally using AutoDock 4.2 program into ER- $\alpha$ (PDB ID: 3UUC). Docking study showed that phenol group of compound 2 interacted with the amino acid E353 of ER- $\alpha$ through $\mathrm{H}$-bonding and the bulky side chain ( $n$-Propyl) present at the central carbon atom of bisphenol A directed towards the amino acid M421 of ER- $\alpha$.
SAR: Thus, introduction of alkyl chains at central carbon atom switched it from agonist to antagonist and presence of two methyl groups at the 3 and $3^{\prime}$-positions improved the antagonistic activity and selectivity for ER- $\alpha$ over ER- $\beta$ (Fig. 5).

\section{Conjugated heterocyclic scaffolds}

Parveen et al. [15], developed new conjugates of pyrimidine-piperazine, chromene and quinoline. Antiproliferative activity of the synthesized conjugates was determined against (MCF-7) tumor cell line using MTT assay. Among these conjugates, compound 3, (2-(4-(2-methyl- 


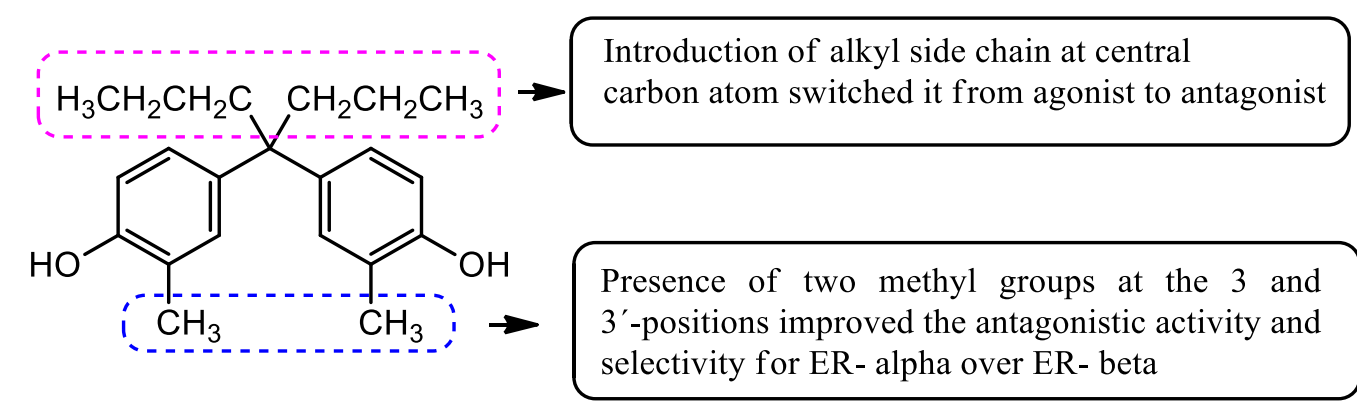

Fig. 5 Structure activity relationship study of compound $\mathbf{2}$

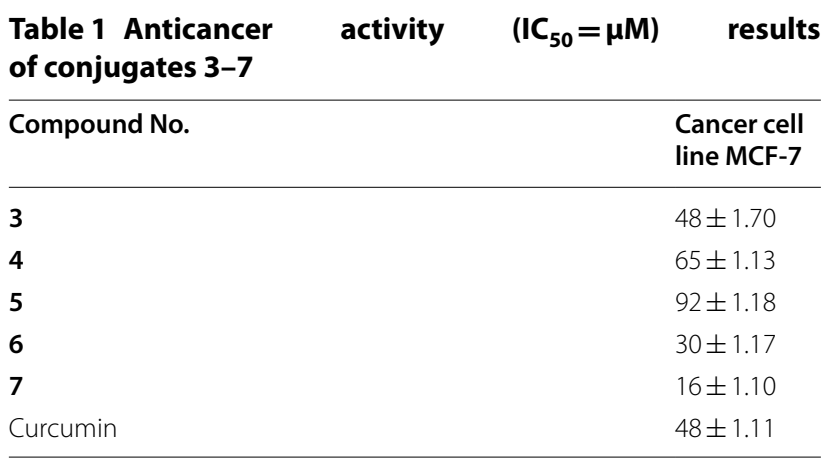

6-((4-p-tolyl-1,4-dihydroquinolin-7-yloxy)methyl) pyridin-4-yl)piperazin-1-yl) ethanol), 4, (2-(4-(2-methyl6-((4-phenyl-1,4-dihydroquinolin-7-yloxy)methyl) pyridin-4-yl) piperazin-1-yl ethanol), 5, (2-(4-(2-methyl6 - ( ( 4 - p henyl - 4H - ch romen - 7 - yloxy ) methyl) pyridin-4-yl)piperazin-1-yl)ethanol), 6, (2-(4-(2-methyl6 - ( (4- ( 4 - nitrophenyl) - $4 H$ - chromen - 7 - yloxy $)$ methyl)pyridin-4-yl)piperazin-1-yl) ethanol) and 7 , (2-(4-(2-methyl-6-((4-p-tolyl-4H-chromen-7-yloxy) methyl)pyridin-4-yl)piperazin-1-yl)ethanol) showed good anti-proliferative activities as compared to standard

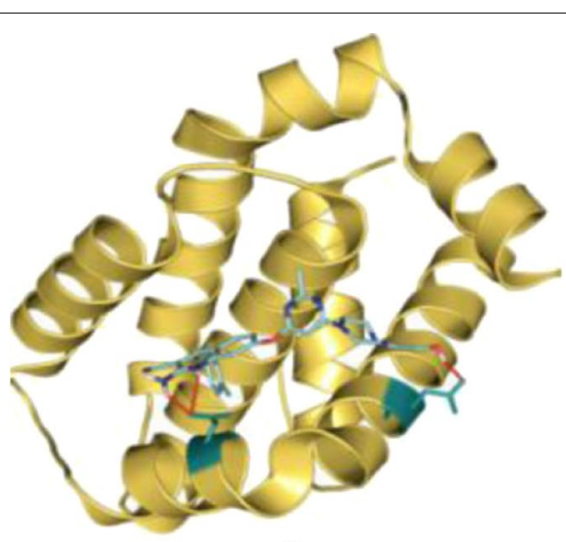

3

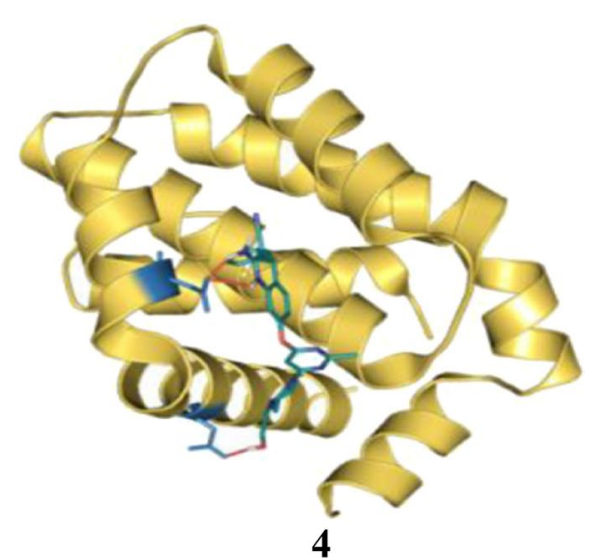

4

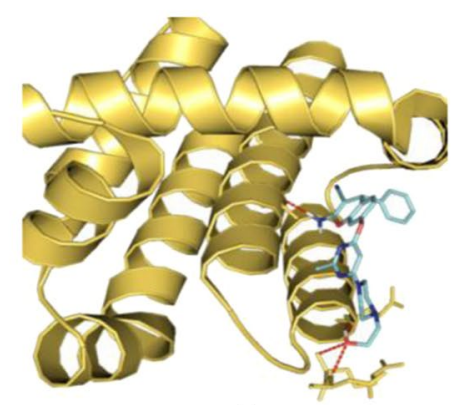

5

Fig. 6 Pictorial presentation of best conformation of compounds 3-5 
curcumin (Table 1, Fig. 3). Molecular docking of most active compounds $3, \mathbf{4}$ and 5 against 3D structure of Bcl-2 protein was performed using Autodock 4.2 (Fig. 6). The Lamarckian genetic algorithm (LGA) was applied to study the protein-ligands interactions. The $p$-tolyl present in compound 3 and phenyl group present in compound $\mathbf{4}$ formed three hydrogen bond one with amino acid Asp100 and two with amino acid Asp108 respectively. The chromene ring in compound $\mathbf{5}$ formed four hydrogen bond with Glu133, Ala146, Arg136 and Asp137 with good binding interaction having binding energy $(\Delta \mathrm{G})-7.70 \mathrm{kcal} / \mathrm{mol}, \mathrm{Ki}=2.26 \mu \mathrm{M})$. The most favorable binding within the active sites of BCL-2 was shown by compounds 3 and $\mathbf{4}$ with minimum binding energy $(\Delta G)=-9.08 \mathrm{kcal} / \mathrm{mol}$ and $(\Delta G)=-8.29 \mathrm{kcal} / \mathrm{mol}$, respectively.

SAR: Structure-activity relationship study showed that the anticancer potential improved when chromene and quinoline nucleus combined with piperazine and pyrimidine rings.

\section{Aromatase inhibitors/selective estrogen receptor modulator}

Zhao et al. [16], designed and synthesized selective estrogen receptor modulators (SERMs) based on diphenylmethylene scaffold by incorporating some of the structural features of the aromatase inhibitor letrozole into lead compound (norendoxifen) by bis-Suzuki coupling to generate a series of selective anti-breast cancer agents to address the problem of $E, Z$ isomerization related with norendoxifen. The functional cellular assay method was employed on MCF-7 cancer cells to evaluate the aromatase inhibitory potential indicated that compound 8, (Fig. 3) was the most active one $\left(\mathrm{IC}_{50}=62.2 \mathrm{nM}\right)$. The binding pattern of the most active one (8) was determined using docking software GOLD3.0 In compound $\mathbf{8}$, the amino substituent present on the phenyl ring that is cis conformation to the nitrophenyl nucleus formed $\mathrm{H}$ - bond with the $\mathrm{OH}$ group of Thr347 while the other amino substituent formed $\mathrm{H}$-bond to the carboxylate of amino acid Glu353 and the backbone bonded to the carbonyl of Phe404 of ER- $\alpha$ (PDB-3ERT) as shown in Fig. 7. The binding affinity of compound $\mathbf{8}$ for both ER- $\alpha$ and ER- $\beta$ was found to be $\left(\mathrm{EC}_{50}=72.1 \mathrm{nM}\right)$ and $\left(\mathrm{EC}_{50}=70.8 \mathrm{nM}\right)$, respectively.

\section{Furan derivatives}

Zimmermann et al. [17], prepared estrogen antagonists by incorporating side chains having amino or sulfur functional groups linked at 3rd position of furan for the breast cancer therapy. The synthesized furan derivatives were determined for their anticancer potential

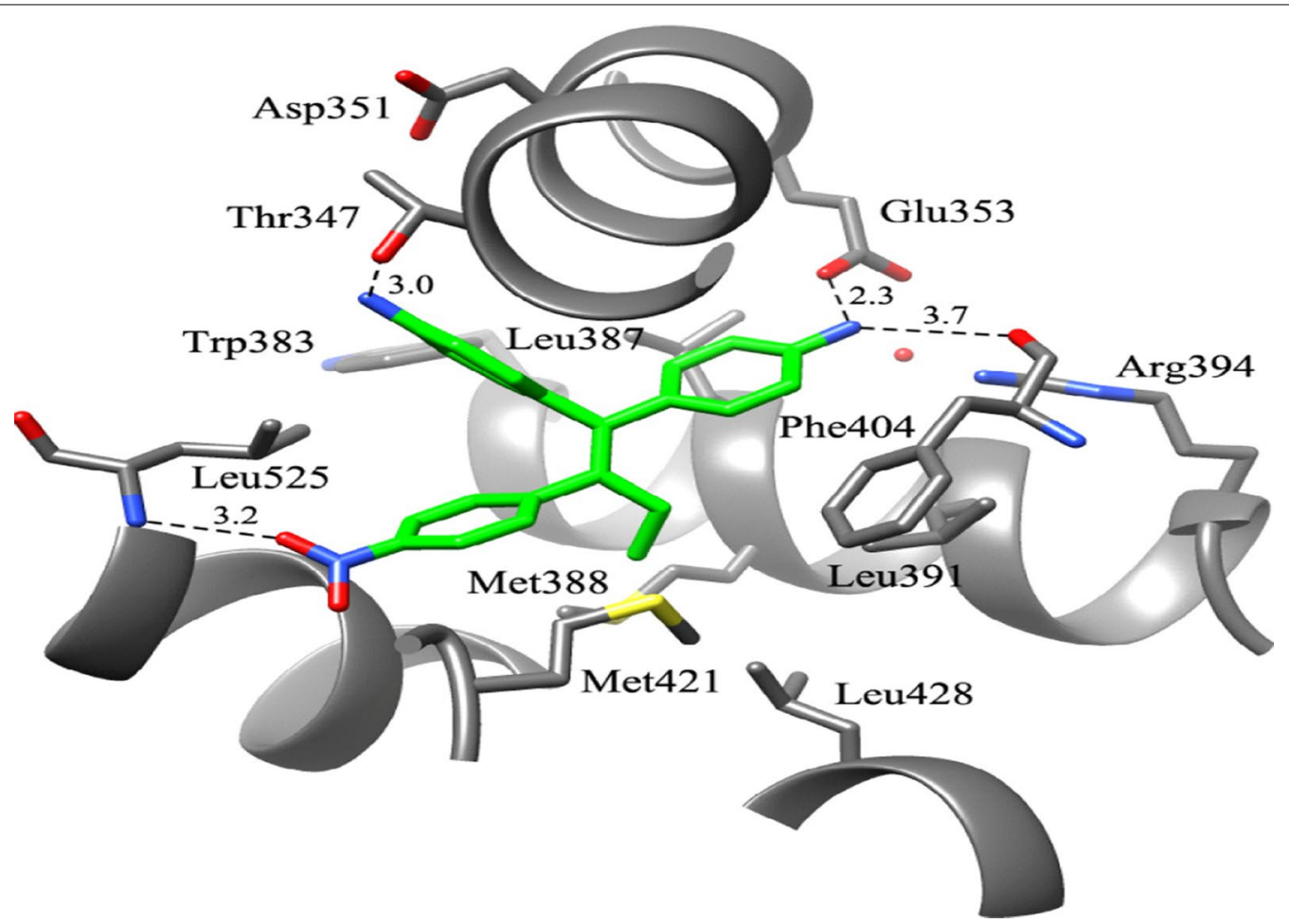

Fig. 7 Docking model of compound 8 
Table 2 Antiestrogenic and antiproliferative activity of compound 9

\begin{tabular}{lll}
\hline Compound No. & $\left(\mathrm{IC}_{\mathbf{5 0}}=\mu \mathrm{M}\right)$ & \\
\cline { 2 - 3 } & Antiestrogenic activity & $\begin{array}{l}\text { Antiproliferative } \\
\text { activity (MCF-7) }\end{array}$ \\
\hline $\mathbf{9}$ & 0.050 & 0.022 \\
Fulvestrant & 0.003 & 0.004 \\
\hline
\end{tabular}

against MCF-7/2a breast cancer cells line. The degree of alpha selectivity increased from 2.5 to 236 times when alkyl group attached at 4th position of furan nucleus. Especially, compound 9, (4,4'-(3-ethyl-4-(6-(methyl(3(pentylthio)propyl)amino)hexyl)furan-2,5-diyl) diphenol showed the strongest antiestrogenic effect (Table 2, Fig. 3). It was found that 2,5-bis(4-hydroxyphenyl)furans with two short alkyl chains have better binding interactions with $\operatorname{ER} \alpha$ than that for $\operatorname{ER} \beta$.

Li et al. [18], prepared new library of 3-acyl-5-hydroxybenzofuran derivatives by microwave-assisted method and evaluated its antineoplastic potential against MCF-7 cell line. Compound 10, [(N-(3-(5-hydroxy-6-methoxybenzofuran-3-carbonyl)phenyl) acetamide), (Fig. 3)] exhibited promising antineoplastic activity against MCF-7 $\left(\mathrm{IC}_{50}=43.08 \mu \mathrm{M}\right)$ compared to tamoxifen using as positive control as evaluated by MTT assay. A quantum mechanics polarized ligand docking (QPLD) study using (PDB code: 1A52) was carried out to interpretate the binding mode between the synthesized molecules and ER- $\alpha$ using Schrödinger Suite 2010. Structural analysis of the most active compound $\mathbf{1 0}$ showed that (Fig. 8) it bound to amino acid residues 5-OH/Leu346, $\mathrm{N}-\mathrm{H} / \mathrm{Th} 347$ of ER- $\alpha$ through $\mathrm{H}$-bonding $(-1.297 \mathrm{kcal} /$ mol) and formed pi-pi conjugate interactions with the benzofuran nucleus and amino acid Phe404. Thus, compound 10 showed the best calculation score (G score $=-10.138 \mathrm{kcal} / \mathrm{mol}$ ) as compared to other synthesized derivatives.

\section{Coumarin conjugates}

Kirkiacharian et al. [19], synthesized a library of estrogen antagonists based on coumarin scaffold with various substitution patterns and their relative binding affinities (RBA) were evaluated for estrogen alpha and beta receptor in Cos cells. Anticancer results showed that compounds substituted at position 3rd and 4th with phenyl group have higher selectivity for ER- $\alpha$ than ER- $\beta$. In this study, compound, 11, [(3,4-diphenyl-7-hydroxycoumarin), (Fig. 9)] showed 13.5 times higher selectivity for estrogen alpha receptor than estrogen beta receptor.

Mokale et al. [20], synthesized a class of coumarinchalcone hybrids by fusing various pharmacophores and determined their antineoplastic activity against MDA-MB-435 MCF-7 breast cancer cell lines using Sulforhodamine B assay. The compound 12, showed highest antineoplastic potential compared to standard drug (tamoxifen). Anticancer potential demonstrated that the

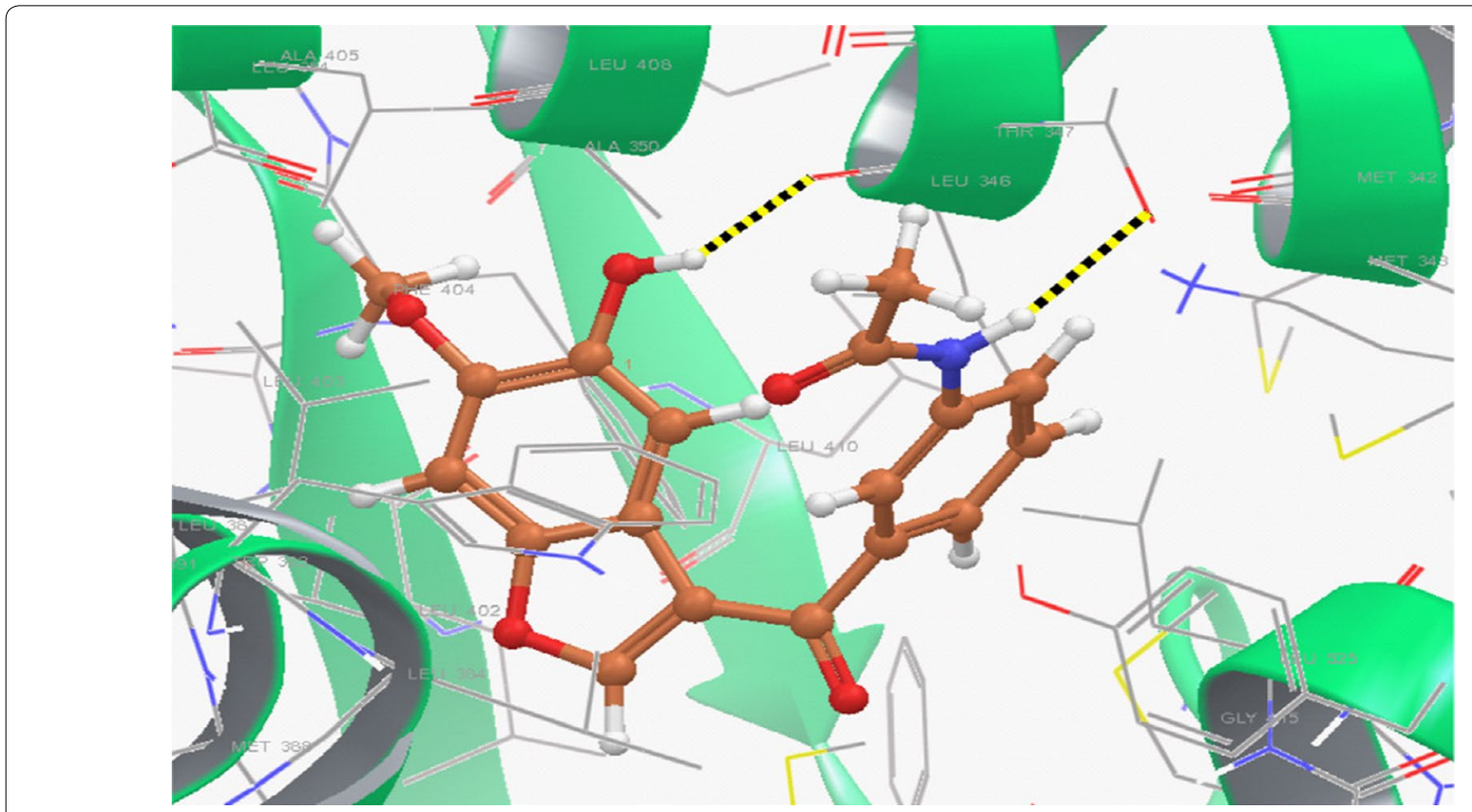

Fig. 8 Pictorial presentation of compound $\mathbf{1 0}$ 
<smiles>O=c1oc2cc(O)ccc2c(-c2ccccc2)c1-c1ccccc1</smiles>

11<smiles>COc1ccc(-c2c(Nc3ccc(OCCN4CCCCC4)cc3)c3ccc(O)cc3oc2=O)cc1</smiles>

14<smiles>CCO[C@H]1C[C@H]2[C@@H]3CCc4cc(O)ccc4C3=C3CC[C@H]2[C@@]1(C)CC3</smiles>

17<smiles>O=C(/C=C/c1ccc(OCCN2CCCCC2)cc1)c1cc2ccccc2oc1=O</smiles><smiles>COc1ccc(/C(=C2\C(=O)Oc3cc(OC)ccc32)c2ccc(OCN3CCCCC3)cc2)cc1</smiles>

12<smiles>CCCOc1cc2c(cc1CNC(=O)Nc1cccc(Br)c1)OS(=O)(=O)N2</smiles>

15<smiles>[R]c1ccc(/N=C(\C)c2ccc(O)c(O)c2)cc1</smiles>

a $\mathrm{R}=\mathrm{CH}_{3} ; \mathbf{b} \mathrm{R}=\mathrm{OH}$
13<smiles>C/C=C1/[C@H](O)C[C@H]2[C@@H]3CCc4cc(OC)ccc4C3=CC[C@]12C</smiles>

16

18

19

Fig. 9 Molecular structures of compounds (11-19)

Table 3 In vitro antiproliferative activity $\left(I C_{50}=\mu \mathrm{g} / \mathrm{mI}\right)$ of compound 12

\begin{tabular}{|c|c|c|c|c|c|c|}
\hline \multirow[t]{2}{*}{ Compound No. } & \multicolumn{6}{|c|}{ Cancer cell lines } \\
\hline & \multicolumn{3}{|c|}{ MCF-7 } & \multicolumn{3}{|c|}{ MDA-MB-435 } \\
\hline \multirow[t]{2}{*}{12} & $\mathrm{LC}_{50}$ & $\mathrm{TGl}$ & $\mathrm{Gl}_{50}$ & $\mathrm{LC}_{50}$ & $\mathrm{TGl}$ & $\mathrm{Gl}_{50}$ \\
\hline & 74.5 & 40 & $<10$ & $>80$ & 78.2 & 75.3 \\
\hline Tamoxifen & 29.5 & 11.2 & $<10$ & 54.2 & 21.5 & $<10$ \\
\hline
\end{tabular}

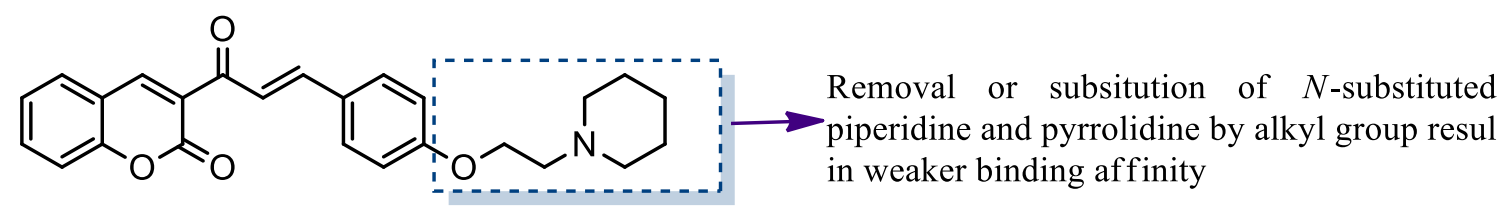

Fig. 10 Structure activity relationship study of compound $\mathbf{1 2}$

compound having amine side chain with piperidine ring have good binding affinity (Table 3, Figs. 9 and 10). Docking study was performed using Glide v5.8 (Schrödinger, LLC) to explore binding interactions of synthesized compounds with estrogen receptor alpha. Coumarin nucleus and 4-ethoxy piperidine side chain of compound 12 interacted deeply within the hydrophilic pocket of ER- $\alpha$ and formed strong $\mathrm{H}$-bonding with Asp351 similar to standard tamoxifen and raloxfiene (Fig. 11). In addition, 


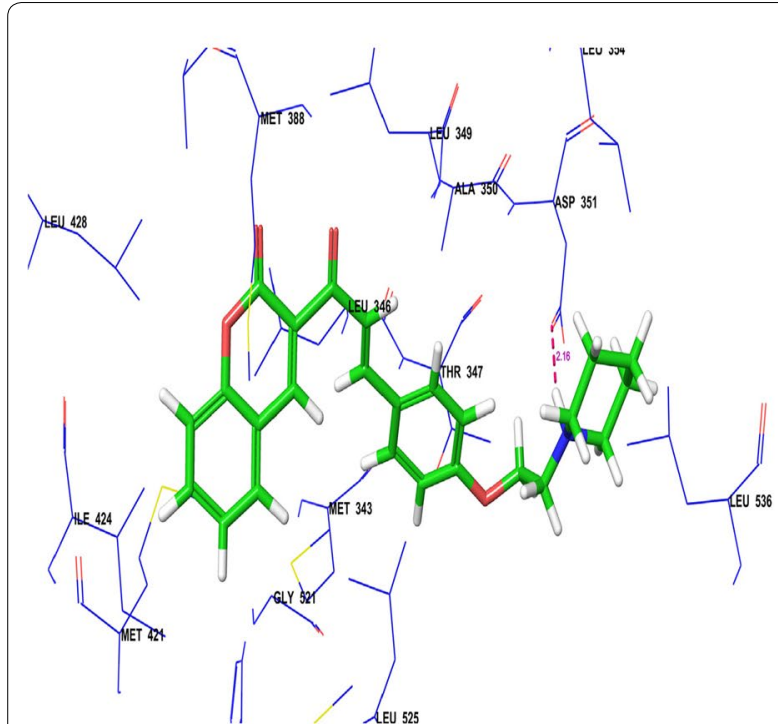

12

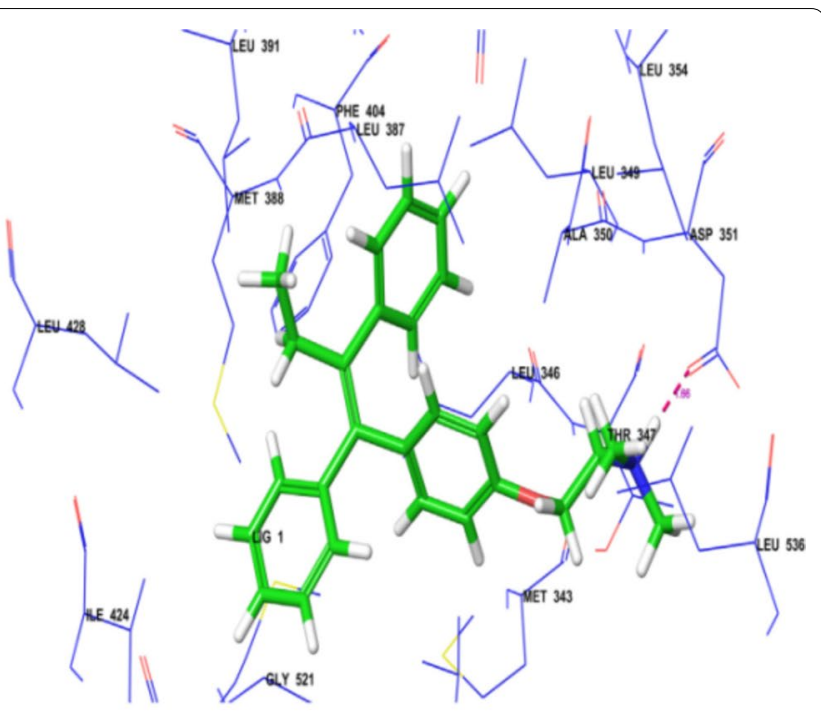

Tamoxifen

Fig. 11 Pictorial presemtation of compound $\mathbf{1 2}$

Table 4 In vitro anticancer results of 13-14

\begin{tabular}{lcr}
\hline Compound No. & \multicolumn{2}{l}{ Tumor cell lines $\left(\mathbf{I C}_{\mathbf{5 0}}=\boldsymbol{\mu M}\right)$} \\
\cline { 2 - 3 } & \multicolumn{1}{c}{ MCF-7 } & \multicolumn{1}{c}{ Ishikawa } \\
\hline $\mathbf{1 3}$ & $4.52 \pm 2.47$ & $11.58 \pm 3.81$ \\
$\mathbf{1 4}$ & $7.31 \pm 2.12$ & $8.43 \pm 1.06$ \\
Tamoxifen & $11.35 \pm 3.13$ & $16.47 \pm 2.04$ \\
\hline
\end{tabular}

compound 12 also showed pi-pi stacking interactions with Phe404 similar to tamoxifen.

Luo et al. [21], prepared new class of chromene derivatives as potential selective antagonists for ER subtypes.
The anticancer results indicated that piperidyl substituted compounds, 13 and 14 exhibited potent antineoplastic activity against MCF-7 and Ishikawa tumor cell lines by MTT assay and showed good ER- $\alpha$ binding affinity (Table 4, Fig. 9). Molecular docking, a deeper binding mode analysis was performed on the promising compounds 13 and 14 having structural diversities on the C-7 position of coumarin skeleton using Discovery Studies 3.0/CDOCKER protocol targeting ER- $\alpha$. The basic side chains of compounds 13 and 14 pointed toward Asp351 to generate an antagonistic conformation similar to Tamoxifen as shown in (Fig. 12). The two methoxy groups containing compound $\mathbf{1 3}$ formed two hydrogen

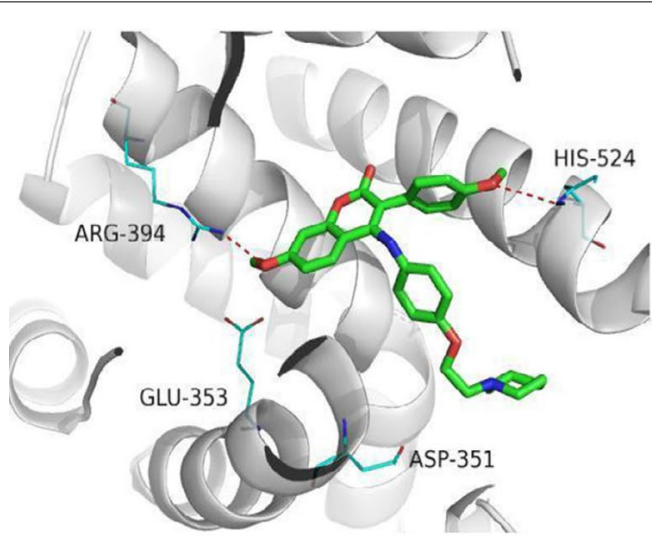

13

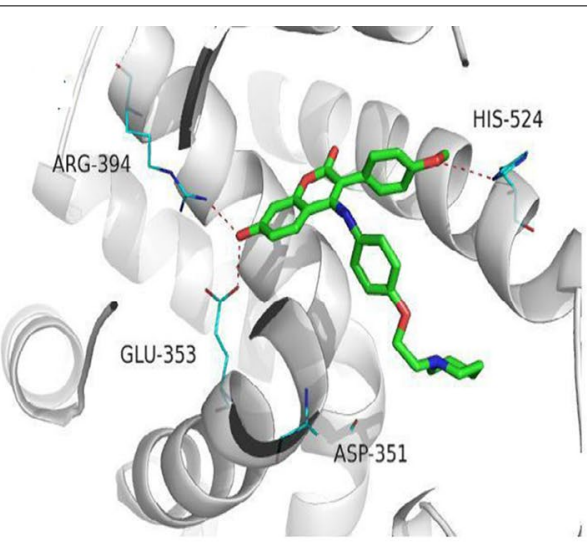

14

Fig. 12 Pictoial presentation of compound $\mathbf{1 3}$ and $\mathbf{1 4}$ 


\section{Replacement of $\mathrm{H}$ or $\mathrm{OMe}$ group with $\mathrm{OH}$ leads to slightly decrease in anticancer activity}

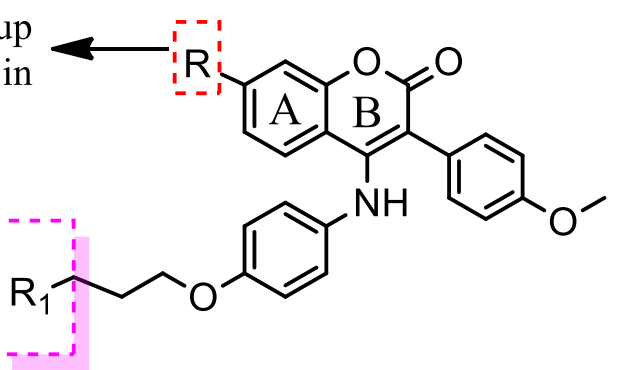

Fig. 13 Structure activity relationship study of compound $\mathbf{1 3}$ and $\mathbf{1 4}$

bonds with Arg394 and His524, respectively. The plausible binding mode of 14 was that it formed two $\mathrm{H}$ - bonds with Glu353 and Arg394 amino acid residues in the hinge region of estrogen receptor alpha through $7-\mathrm{OH}$.

SAR: From this series, compound $\mathbf{1 4}$ containing hydroxyl group displayed the best ER- $\alpha$ binding affinity $(\mathrm{RBA}=2.83 \%)$, while compound 13 bearing methoxy group displayed the best in vitro antineoplastic potential against MCF-7 carcinoma cell line (Fig. 13).

\section{Inverse agonist}

ERR $\alpha$ is the orphan nuclear receptor (ONR) which is identified homologous to estrogen receptor alpha at DNA-binding domain, indicated that ERR $\alpha$ inflect the actions of estrogen alpha receptor. Thus, ERR $\alpha$ act as a prognostic marker in breast malignancy.

Ning et al. [22], synthesized a novel compound as a selective inverse agonist of estrogen-related receptor and determined for its anticancer activity against triple negative breast cancer cells (MDA-MB-231) and found that compound 15 [(1-(4-(methyl-sulfonamido)-2,5-dipropoxybenzyl)-3-(3-bromophenyl)urea), (LingH2-10), (Fig. 9)] as a potential ligand that selectively inhibited

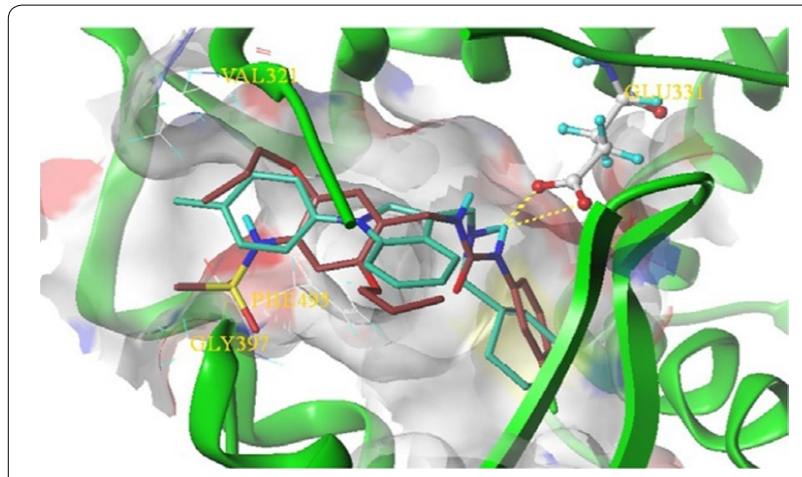

Fig. 14 Superimposition of docking model of compound 2PJL ligand (cyan) and compound $\mathbf{1 5}$ (reddish brown) was docked into ERRa crystal structure. Dotted yellow lines shows hydrogen binding interactions the ERR $\alpha$ transcriptional activity and inhibited the cancer cell growth both in vitro and in vivo. The 3D docking simulations of compound 15 (LingH2-10, Fig.14) demonstrated within the binding pocket of ERR $\alpha$ using surflexdock geomx program (Sybyl X2.0). The 3-bromo-phenyl group in LingH2-10 occupied the position interacted with the receptor ERR through hydrophobic interactions. One of the amino in the ureido group in LingH2-10 formed $\mathrm{H}$ - binding interaction with the residue Gly397 of ERR $\alpha$ receptor. The methane sulfonamide group at the end of LingH2-10 stretched downwards into the cavity formed by the residues Phe495 and Gly397 possibly with some polarity interactions. In order to carry out the in vivo studies, breast tumor xenografts were developed in nude mice. The 10 doses of compound $15(30 \mathrm{mg} / \mathrm{kg})$ were given on alternate days. After the treatment, the results demonstrated that there is $42.20 \%$ inhibition of tumor growth such as in mice the volume of tumor in treated xenografts was $810 \mathrm{~mm}^{3}$ while in control it was $1397 \mathrm{~mm}^{3}$. These results demonstrated that the compound $\mathbf{1 5}$ might act as lead molecule.

\section{Steroidal analogs}

Alsayari et al. [23], synthesized a new class of estrone based analogs were investigated for their anticancer activity using MTT assay. Compounds, 16 and 17 (Figs. 9 and 15) exhibited significant inhibitory estrogenic profile. In silico molecular docking simulations carried out by competitive binding assay revealed that compound 16 has very similar binding mode $\left(\mathrm{IC}_{50}=5.49 \mu \mathrm{M}\right)$ to estradiol $\left(\mathrm{IC}_{50}=0.0069 \mu \mathrm{M}\right)$ on estrogen alpha receptor through $\mathrm{H}$-bonding interaction between the methoxy group present at 3rd position in steroidal nucleus and amino acid residue in ARG: 394.

\section{Reseveratrol (phytoestrogen) analogs}

Siddqui et al. [24], synthesized a library of reseveratrol analogs and evaluated its anticancer potential against T47D, MDA-MB-231 breast tumor cells using MTT 


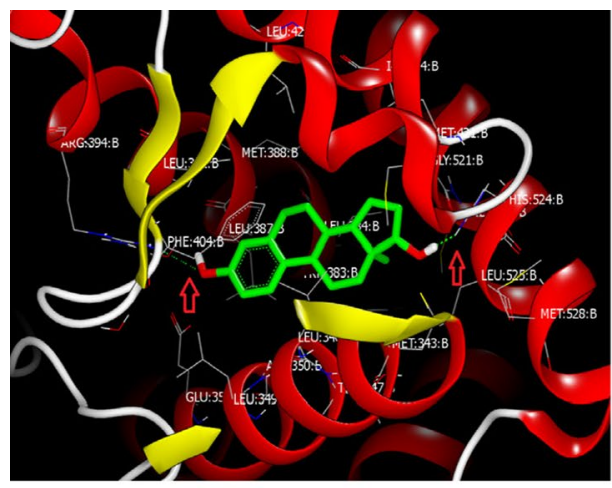

16

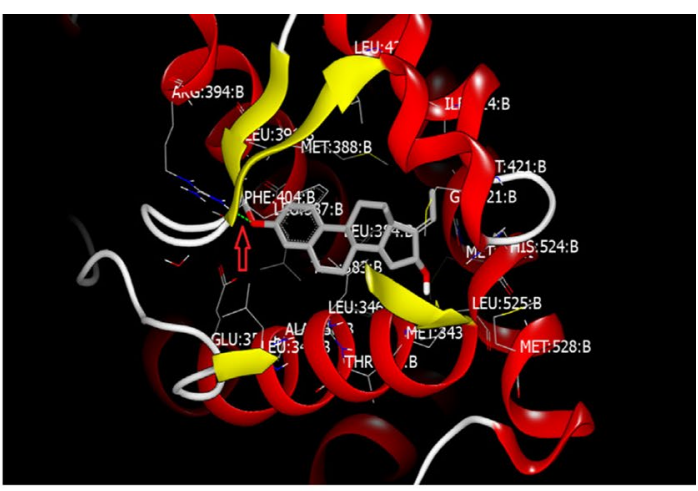

17

Fig. 15 Visual presentation of compound $\mathbf{1 6}$ and $\mathbf{1 7}$ with receptor ER $a$. Dotted red lines show the hydrogen bond formation

Table 5 Anticancer activity $\left(I C_{50}=\mu \mathrm{M}\right)$ results of reseveratrol analogs 18 ( $a$ and $b$ )

\begin{tabular}{lll}
\hline Compound No. & \multicolumn{2}{l}{ Cancer cell lines } \\
\cline { 2 - 3 } & MDA-MB-239 & T47D \\
\hline a & 21 & 32 \\
b & 29 & 44 \\
Resveratrol & 66 & 76 \\
\hline
\end{tabular}

assay. The molecular docking study showed the binding pattern of aza-resveratrol analogs with estrogen receptor alpha indicated the presence of additional hydrogen bonding and tight binding interactions with active sites of protein cavity of estrogen receptor alpha. Among the synthesized compounds, 18 (a, ( $(E)-4-(1-(p$-tolylimino) ethyl)benzene-1,2-diol) and (b, ((E)-4-(1-(4-hydroxyphenylimino)ethyl)benzene-1,2-diol)) exhibited potent

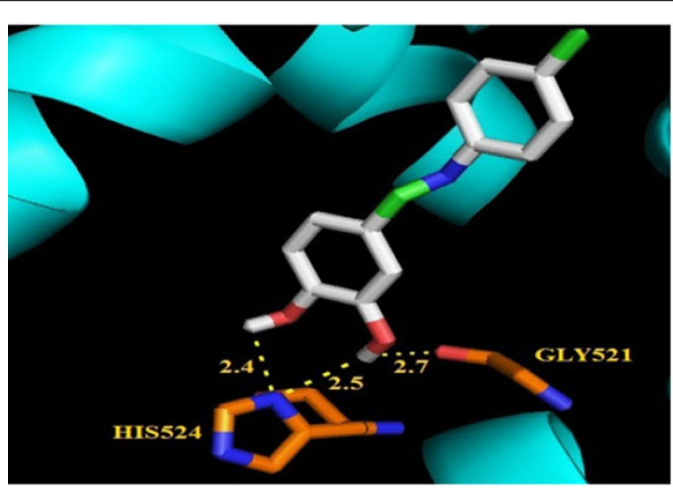

18 (a)

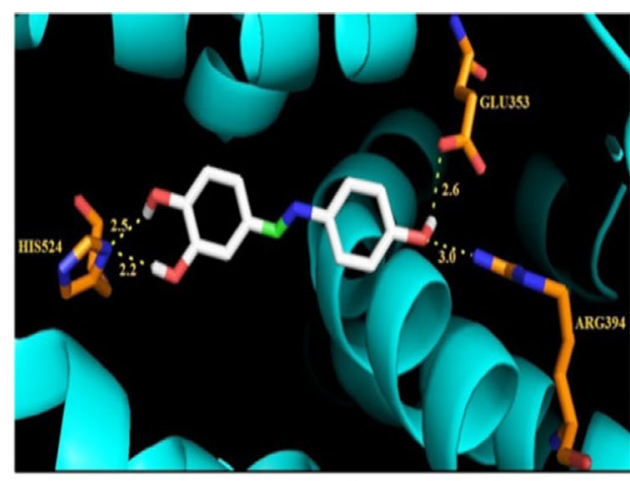

18 (b)

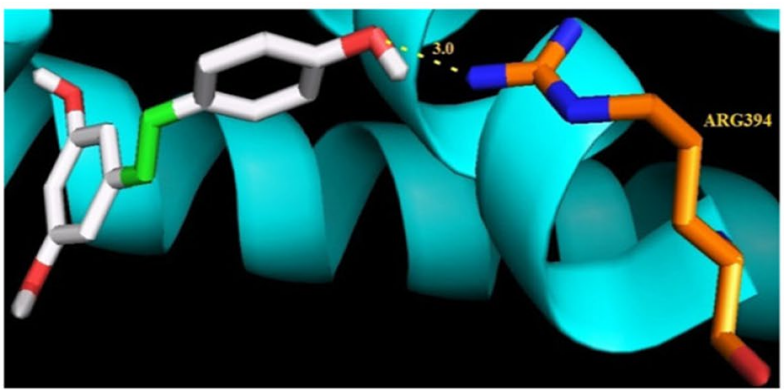

Reservatol

Fig. 16 Pictorial presentation of compounds $\mathbf{1 8}(\mathbf{a}, \mathbf{b})$ and reservatol 


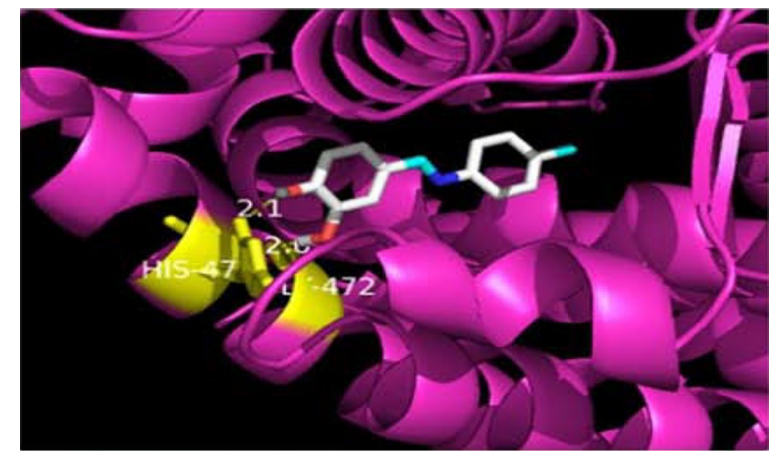

Fig. 17 Pictorial pesentation of compound 19

Table 6 Cytotoxicity $\left(\mathrm{IC}_{50}=\mu \mathrm{M}\right)$ of triarylethylene analogs (20-22)

\begin{tabular}{lll}
\hline Compound No. & \multicolumn{2}{l}{ Cancer cell lines } \\
\cline { 2 - 3 } & MDA-MB-231 & MCF-7 \\
\hline $\mathbf{2 0}$ & $11.4 \pm 4.2$ & $16.9 \pm 7.7$ \\
$\mathbf{2 1}$ & $16.9 \pm 7.7$ & $>50$ \\
$\mathbf{2 2}$ & $12.2 \pm 5.3$ & $>50$ \\
Tamoxifen & $>50$ & 50 \\
Ospemifene & $>50$ & $>50$ \\
\hline
\end{tabular}

antibreast cancer activity as compared to resveratrol against both cell lines (Table 5, Fig. 9). The anticancer results demonstrated that incorporation of the iminogroup in the parent resveratrol enhanced its anticancer potential. Molecular docking of the most active synthesized resveratrol analogs a and b was performed in estrogen receptor alpha protein cavity to observe their binding pattern as shown in Fig. 16. The vicinal hydroxyl groups on ring $\mathrm{A}$ of compound $\mathbf{b}$ undergo $\mathrm{H}$-bonding with HIS524 residues while methyl group interacted with ARG394 and GLU354 residues, respectively. The 3, 4-dihydroxyl groups on ring A in compounds 18 (a and b) favored Van der Waals interactions with amino acid residues in the ER- $\alpha$ protein leading to stabilization of these ligands into the protein cavity. Compounds 18 (a and b) displayed potent activity against MDA-MB-231 (with $65-75 \%$ cytotoxicity) and T47D cells (with 40-60\% cytotoxicity), while resveratrol induced only $40 \%$ cytotoxicity against both tested cell lines.

Resveratrol, a natural phytoestrogen, have potent antineoplastic properties but its poor efficacy and bioavailability have limited its clinical applications. In order to overcome these difficulties, Ronghe et al. [25] synthesized aza-resveratrol analogs and tested for their antineoplastic activity against MDA-MB-231, T47D and MCF-7 breast tumor cells using MTT assay. The in vitro anticancer results showed that compound 19, [4- $(E)-\{(p$-tolyl imino)-methylbenzene-1,2-diol\}, Figs. 9 and 17] showed better anticancer properties than parent resveratrol [19].

\section{Triarylethylene analogs}

Kaur et al. [26], developed novel derivatives of triarylethylene and determined their in vitro cytotoxic potential against ER- (MDAMB-231) and ER+ (MCF7) human breast cancer cell using MTT assay.<smiles>COc1ccc(C(=C(CCN)c2ccccc2)c2ccccc2)cc1</smiles>

20<smiles>CCCn1c(-c2ccc(O)cc2)c(C)c2cc(O)ccc21</smiles>

23

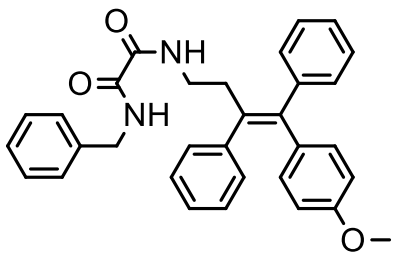

21<smiles></smiles>

24

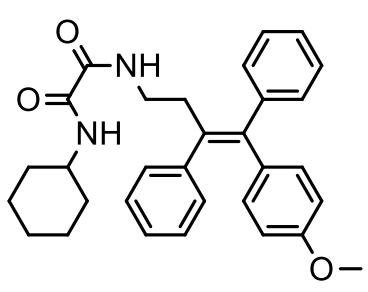

22<smiles>[R]c1ccccc1N1CCN(C(=O)c2n[nH]c3c2CSc2sccc2-3)CC1</smiles>

25

Fig. 18 Molecular structures of compounds (20-25) 
Compounds 20, 21 and 22 displayed better anticancer activity than standard drug (tamoxifen, ospemifene) (Table 6, Fig. 18). Especially, compound 20 suppressed the expression of c-Myc, MMP-9 and caveolin in both MDA-MB-231 and MCF-7 cells. In silico, docking simulations performed using the CDocker docking algorithm indicated that compound $\mathbf{2 0}$ have good binding affinity with estrogen receptors (ERs).

SAR: The structure activity relationship study demonstrated that the presence of amino or oxalamido substituents on 20, 21 and 22 increases the potency and selectivity against both ER- and ER+ tumor cell lines.

\section{Indole derivatives}

Kelley et al. [27], prepared a library of selective estrogen receptor modulators based on the 2-arylindole scaffolds to selectively target the estrogen receptor in hormone positive breast cancers (MCF-7). Among the synthesized compounds, compounds 23 and 24 (Table 7, Fig. 18) demonstrated strong estrogen receptor (ER) binding (Fig. 19) as evaluated by Fred 3.0.1. and also exhibited good anticancer potential in ER responsive MCF-7 cell with minimal residual effects as evaluated by AlamarBlue assay.

\section{Pyrazole derivatives}

Sun et al. [28], synthesized a new class of 1,4-dihydrothieno $\left[3^{\prime}, 2^{\prime}: 5,6\right]$ thiopyrano[4,3-c]pyrazole-3-carboxylic amides and assessed their anticancer potential against MCF-7 tumor cell line by MTT method and compared to positive control (tamoxifen). Among the target compounds, compounds $\mathbf{2 5}$ (a and $\mathbf{b}$ ) were found to be more active against selected cell line (Table 8 , Fig. 18).

SAR: The structure activity relationship study showed that compounds $\mathbf{2 5}$ (a and $\mathbf{b}$ ) having substitution $\left(\mathrm{OCF}_{3}\right.$ and $\mathrm{OCH}_{3}$ ) at 4th position of benzene ring plays a vital role in antitumor activity.

Stauffer et al. [29], developed a new class of pyrazoles and evaluated their antiproliferative activity by cellbased transfection assay. $N$-piperidinyl-ethyl chain was introduced at all the four sites of substitution on the pyrazole ring to observe the binding mode in the ER

Table 7 Anticancer results $\left(\mathrm{IC}_{50}=\mu \mathrm{M}\right)$ of indole analogs (23-24)

\begin{tabular}{ll}
\hline Compound No. & $\begin{array}{l}\text { Cancer cell } \\
\text { line MCF-7 }\end{array}$ \\
\hline $\mathbf{2 3}$ & 2.71 \\
$\mathbf{2 4}$ & 1.86 \\
\hline
\end{tabular}

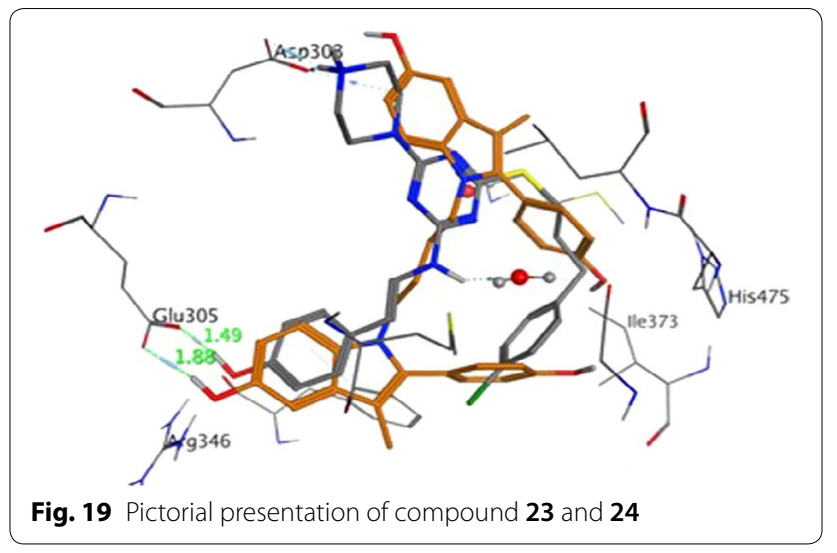

Table 8 Cytotoxic results of pyarzole derivatives 25 (a and b)

\begin{tabular}{lll}
\hline Compound No. & \multicolumn{2}{l}{ MCF-7 cancer cell line } \\
\cline { 2 - 3 } & Inhibition rate \% & $\mathbf{I C}_{\mathbf{5 0}}=\mathbf{\mu m o l} \mathbf{L}$ \\
\hline a & 71.09 & 90.63 \\
$\mathbf{b}$ & 88.86 & 72.55 \\
Tamoxifen & 100 & 55.89 \\
\hline
\end{tabular}

ligand binding pocket. Piperidinyl-ethoxy-substituted pyrazole at 5th position of 26 (Fig. 20)] was found to be the most active one $\left(\mathrm{IC}_{50}=20 \mathrm{nM}\right)$ against lamb uterine cytosol. Docking studies carried out using Flexidock routine within SYBYL 6.5.2 demonstrated that compound 26 (Fig. 21) showed 20-fold higher selectivity and binding affinity for ER- $\alpha(11.5 \pm 1)$ than ER- $\beta$ $(0.650 \pm 0.02)$.

\section{Hydrazones}

Dadwante et al. [30], prepared plumbagin hydrazonates and screened for their cytotoxic potential against MCF-7 $(\mathrm{ER}+\mathrm{ve})$ and triple negative MDA-MB-231and MDAMB-468 breast tumor cell lines by MTT assay. The hydroxyl group of plumbagin was found to be essential for the inhibition of histone acetyltransferase activity of p300/CBP, which is a transcriptional activator of ER- $\alpha$. In particular, compound 27 (a (5-hydroxy-2-methyl-4(2-(1-(pyridin-2-yl)vinyl)hydrazono) naphthalen-1(4H)one)) and (b (5-hydroxy-2-methyl-4-(2-(1-phenylvinyl) hydrazono) naphthalen-1(4H)-one)) was found to be more effective in inhibiting NF-kB expression. Molecular docking studies carried out with the help of Autodock 4.0 to analyze ligand interactions (Fig. 22) with the crystal structure binding site of p50-NF- $\mathrm{kB}$ obtained from PDB ID (1NFK) demonstrated that $\mathrm{OH}$-groups on plumbagin and hydrazonate side chain favor additional 
<smiles>CCc1c(-c2ccc(O)cc2)nn(-c2ccc(O)cc2)c1-c1ccc(OCCN2CCCCC2)cc1</smiles>

26

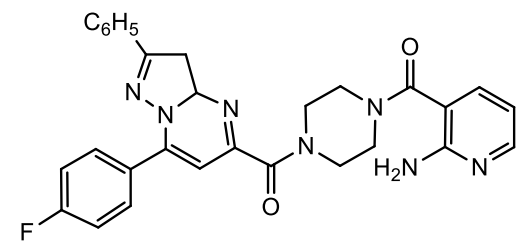

29<smiles>Nc1ccc(-c2ccc3ccc(Cl)cc3n2)cc1</smiles>

32<smiles>O=C1c2ccccc2OCC1c1cccnc1</smiles>

35<smiles>C=C([Al])NN=C1C=C(C)C(=O)c2cccc(O)c21</smiles>

a Ar-3-methylpyridine

b Ar-toluene

27<smiles>COc1ccc(C2=CC(C(=O)N3CCN(C(=O)c4cccnc4Nc4ccccc4)CC3)=NC3CC(c4ccccc4)=NN23)cc1</smiles>

30<smiles>O=C1c2ccccc2OCC1c1ccc(Oc2ccccc2)cc1</smiles>

33<smiles>CC1(C)CCC(=O)C2=C1OC1=C(C(=O)CCC1)C2c1cc2ccccc2n1Cc1ccccc1</smiles>

36

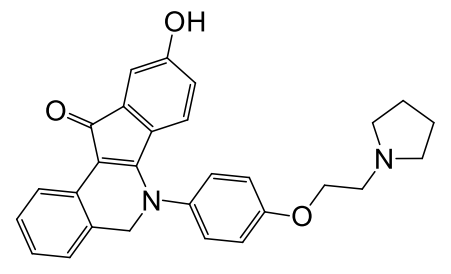

28<smiles>COc1ccc(-c2cnc(-c3ccc(OC)cc3)o2)cc1</smiles>

Fig. 20 Molecular structures of compounds (26-37)

H-bonding with amino acid which may be responsible for the improved anticancer potential. The binding energies were in the range of -7.43 to $-7.88 \mathrm{kcal} / \mathrm{mol}$ which are greater than that of the parent plumbagin compound, indicated strong binding interactions in the active site of p50-subunit of NF- $\mathrm{kB}$ protein enhanced through H-bonding interaction with GLY66 and HIS64 amino acid, respectively (Table 9, Fig. 20)

\section{Isoquinoline derivatives}

Tang et al. [31], synthesized and structurally characterized a series of 6-aryl-indeno isoquinolone inhibitors targeting ER $\alpha$ to improve efficacy as compared to tamoxifen. The synthesized derivatives presented good ER $\alpha$ binding affinity and antagonistic activity and also showed excellent anticancer activity against MCF-7 using MTT assay. In this series, compound 28, (Fig. 20)] exhibited promising anticancer activity $\left(\mathrm{IC}_{50}=0.5 \mu \mathrm{M}\right)$ which is 27-times greater anticancer potential than the reference drug tamoxifen $\left(\mathrm{IC}_{50}=13.9 \mu \mathrm{M}\right)$. Docking studies carried out with Discovery Studio.2.5/CDOCK protocol to explore binding pattern of compound 28 in ER- $\alpha$ indicated that compound $\mathbf{2 8}$ favorably docked with the active sites of ER- $\alpha$ (Fig. 23). The hydroxyl group present at 9th 


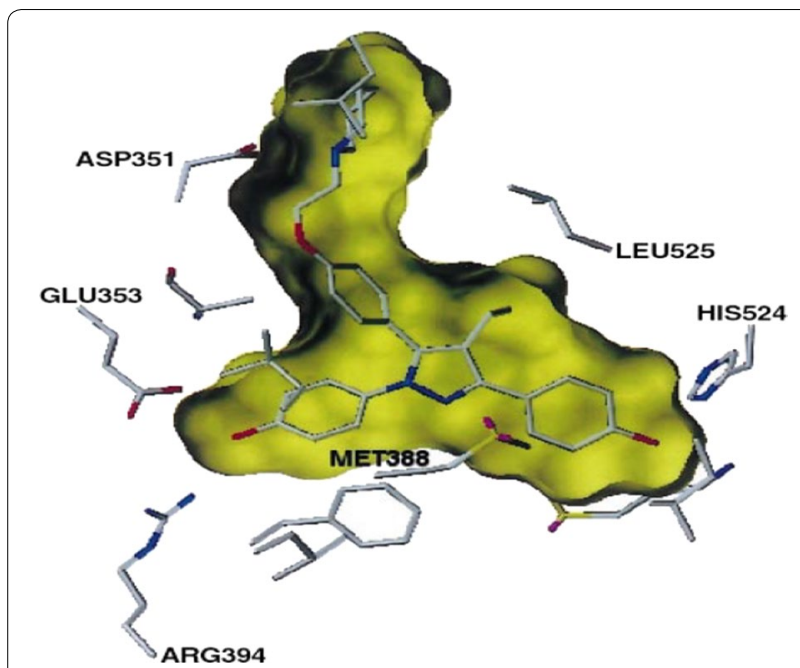

Fig. 21 Pictorial presentation of compound $\mathbf{2 6}$

position in 28 interacted with Glu353 and Arg394 which imitate with the A-ring phenol of estradiol while the hydroxyl group at 3rd position interacted with His524 with similar binding mode as $17 \beta-\mathrm{OH}$ of estradiol. The basic side chain of 28 was oriented to Asp351 such as to generate antagonistic conformation similar to tamoxifen.

\section{Anilinonicotinyl linked pyrazolo[1,5-a]pyrimidine conjugate}

A library of aniline nicotinyl linked pyrazolo[1,5-a] pyrimidine conjugates was prepared by Kamal et al. [32] and evaluated against MCF-7 cancer cell line using MTT assay and compared to standard drug (doxorubicin). Compound 29, (4-(2-aminonicotinoyl) piperazin-1-yl)(7-(4-fluorophenyl)-2-phenyl-3,3adihydropyrazolo[1,5a]pyrimidin-5-yl) methanone) and compound 30, ((7-(4-methoxyphenyl)-2-phenyl-3,3adihydropyrazolo[1,5-a]pyrimidin-5-yl)(4-(2-(phenylamino)nicotinoyl)piperazin-1-yl)methanone), (Table 10, Fig. 20) possessed significant antiproliferative potential against breast carcinoma cells (MCF-7) by affecting interaction between ERE-ER $\alpha$.

\section{Bis(hydroxyphenyl)azoles}

Bey et al. [33], synthesized bis(hydroxyphenyl) azoles and evaluated as selective non-steroidal inhibitors of $17 \beta$-HSD1 for the therapy of estrogen-dependent diseases and the molecular docking was carried out by automated docking program GOLD 3.0, the docked compound 31 shown as yellow within 17 $\beta$-HSD1-binding pocket (green amino acids) (Fig. 24). In this series, compound 31, $\left[\left(\mathrm{IC}_{50}=0.31 \mu \mathrm{M}\right)\right.$, (Fig. 20)] showed good anticancer potential with higher selectivity for ER $\alpha$ with regard to $17 \beta-\mathrm{HSD} 2$ as evaluated by cell free assay. The $p$-hydroxyphenyl substituent lay in the same plane while $m$-hydroxyphenyl substituent of compound 31 laid $32^{\circ}$ out of this plane, respectively. This conformation allowed 31 to create $\mathrm{H}$-bond interactions (shown by violet lines in Fig. 24, distances were expressed in $\AA$ ) with His221/ Glu282 and Ser142/Tyr155 with $p$-hydroxyphenyl nucleus and $m$-hydroxyphenyl nucleus, respectively.

Table 9 Anticancer results of compounds 27 ( $a$ and b)

\begin{tabular}{llcc}
\hline Compound No. & \multicolumn{3}{l}{ Tumor cell lines $\left(\mathrm{IC}_{\mathbf{5 0}}=\boldsymbol{\mu M} \pm \mathrm{S} . \mathrm{E}.\right)$} \\
\cline { 2 - 4 } & MCF-7 & MDA-MB-231 & MDA-MB-468 \\
\hline a & $2.7 \pm 0.32$ & $1.9 \pm 0.28$ & $1.9 \pm 0.25$ \\
b & $2.8 \pm 0.26$ & $2.1 \pm 0.34$ & $2.0 \pm 0.31$ \\
\hline
\end{tabular}

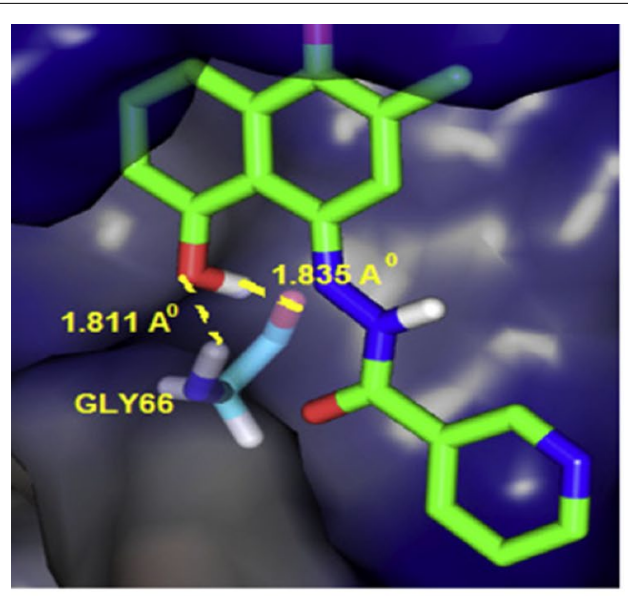

27 (a)

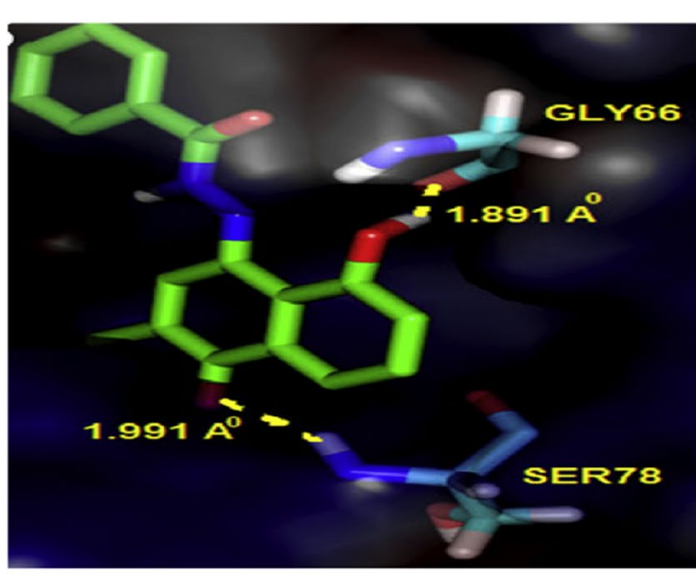

27 (b)

Fig. 22 Pictorial presentation $\mathrm{f}$ compound $\mathbf{2 7}(\mathbf{a}, \mathbf{b})$ 


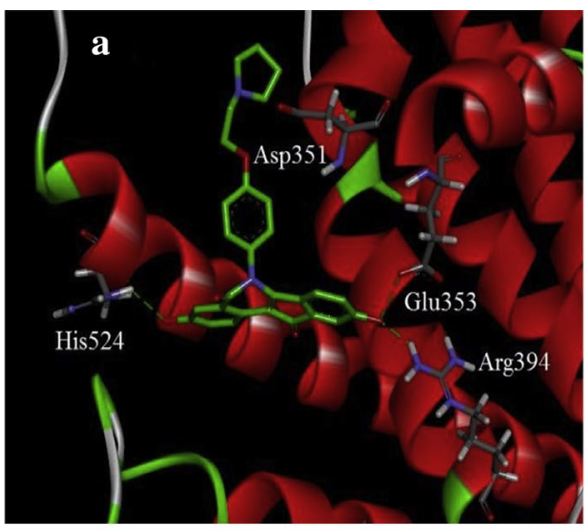

28

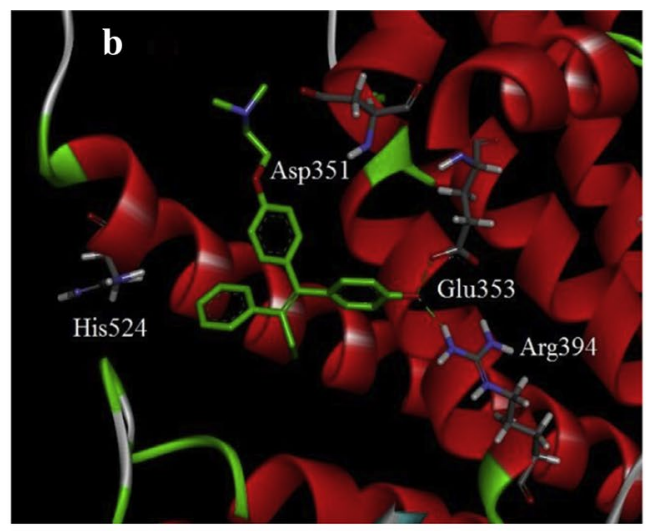

Binding mode of Tamoxifen with ER alpha

Fig. 23 Pictorial presentation of compound $\mathbf{2 8}$ in ER alpha (a) and tamoxifen in ER alpha (b)

Table 10 Anticancer potential of pyrazolo[1,5-a] pyrimidine conjugate (29-30)

\begin{tabular}{ll}
\hline Compound No. & $\begin{array}{l}\mathrm{I} \mathrm{C}_{\mathbf{5 0}}=\boldsymbol{\mu M} \\
\mathrm{MCF}-\mathbf{7} \\
\text { Cancer cell } \\
\text { line }\end{array}$ \\
\hline $\mathbf{2 9}$ & 1.79 \\
$\mathbf{3 0}$ & 2.16 \\
Doxorubicin & $0.473 \mu \mathrm{M}$ \\
\hline
\end{tabular}

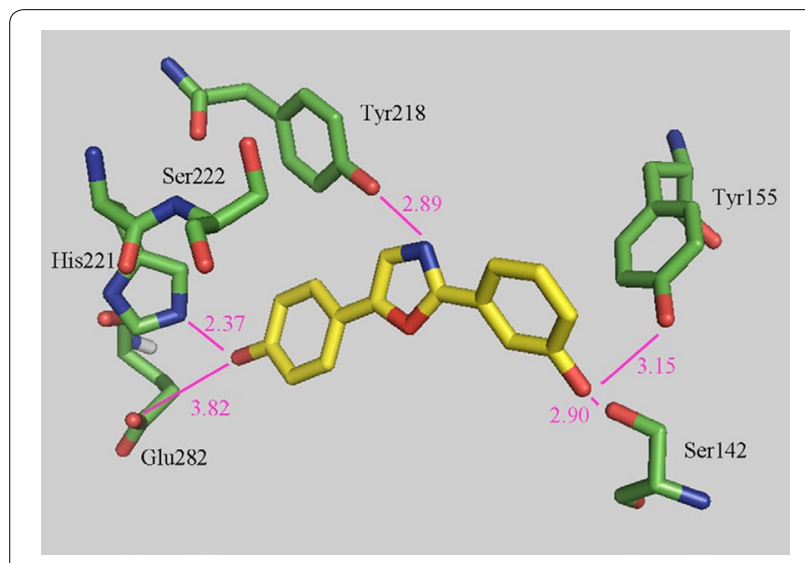

Fig. 24 Pictorial presentation of docked compound $\mathbf{3 1}$

\section{Quinoline analogues}

A novel library of quinoline-based analogs was synthesized by microwave assisted method and its anticancer activity was evaluated against ER $\alpha$ positive human cancer cells by Bharathkumar et al. [34]. Among the synthesized compounds, compound 32, [(4-(7-chloroquinolin-2-yl)benzenamine), (Fig. 20)] hold significant antineoplastic potential. Compound 32 displayed significant anticancer potential against HepG2 and MCF-7 tumor cells having $\mathrm{IC}_{50}$ value of $6 \mu \mathrm{M}$ and $11 \mu \mathrm{M}$, respectively. The structure activity relationship study of compound 32 as displayed in Fig. 25.

\section{Isoflavone derivatives as aromatase inhibitor}

Bonfield et al. [35], designed and synthesized 3-phenylchroman-4-one (isoflavone) derivatives and evaluated their anticancer potential by fluorescence-based assay using recombinant human aromatase using ketoconazole as positive control. Compounds, 33, 34 and 35 (Table 11, Figs. 20 and 26) displayed effective inhibitory activity against aromatase. Docking study was carried out using program GOLD (version 5.0.1.) to observe H-bonding and hydrophobic interactions.

SAR: The structure activity relationship results showed that presence of functional groups $\left(-\mathrm{OCH}_{3}(34),-\mathrm{OPh}\right.$ (33) and $\mathrm{C}_{6} \mathrm{H}-{ }_{5} \mathrm{~N}(35)$ ) displayed good inhibitory activities against aromatase, showing that the non-planarity configuration of the isoflavanone analogs might play vital role in enzyme-ligand binding. Compound $\mathbf{3 4}$ having methoxy substitution at 6 th position of coumarin nucleus was found to be the most active one.

Singla et al. [36], synthesized indole-xanthendione analogs and screened their anticancer potential and estrogen receptor alpha binding affinity utilizing ER $\alpha$ responsive T47D breast cancer cell line. Compounds 36 and 37 displayed most promising anticancer potential targeting on ER- $\alpha$ (Table 12, Fig. 20). RT-PCR and Western blotting experiments indicated that these derivatives 36 and 37 exhibited their anticancer activity by altering the m-RNA and ER- $\alpha$ receptor expression, thus inhibiting further transactivation and signaling in T47D cancer cells. GlideXP (Glide Extra precision) with vdW scaling 0.8 was 


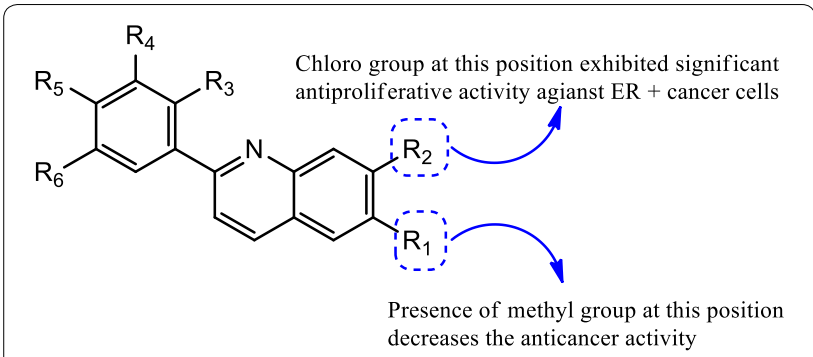

Fig. 25 Structure activity relationship of compound $\mathbf{3 2}$

Table 11 Aromatse inhibitory activity of isflavaone derivatives (33-35)

\begin{tabular}{ll}
\hline Compound No. & $\begin{array}{l}\text { Aromatase } \\
\text { inhibitory } \\
\text { activity } \\
\mathrm{IC}_{\mathbf{5 0}}=\boldsymbol{\mu M}\end{array}$ \\
\hline 33 & 2.4 \\
34 & 0.26 \\
$\mathbf{3 5}$ & 5.8 \\
\hline
\end{tabular}

employed to carry out molecular docking and then ranked them based on the GlideXP score. Induced fit simulation was employed to analyze the binding pattern of compounds $\mathbf{3 6}$ and $\mathbf{3 7}$ with estrogen receptor alpha (PDB: 4XI3) and it showed that these compounds bind in the shallow binding site of the ER- $\alpha$ receptor in similar docking pose as that of the bazedoxifene with strong binding affinity of $-12.51 \mathrm{kcal} / \mathrm{mol}$ and $-12.06 \mathrm{kcal} /$ $\mathrm{mol}$, respectively that is comparable to the bazedoxifene $(-9.33 \mathrm{kcal} / \mathrm{mol})$. The indole moiety present in compounds anchored the xanthendione nucleus in the hydrophobic cavity. These compounds showed hydrogen bond interaction with Arg 394, Lys 529 and Asn 532, respectively (Fig. 27). Compounds 36 and 37 showed extensive Van der Waals forces of interaction with various amino acids listed in Table 12.

SAR: Further, from the structure activity relationship studies it was concluded that increasing the substitution at xanthendione moiety decreases the anticancer activity of the synthesized derivatives.

Singla et al. [37], synthesized indole benzimidazole hybrids to develop novel selective estrogen receptor modulators and investigated their antibreast cancer potential via ER- $\alpha(+)$ T47D cariconoma cell line using MTT assay. From these hybrids, bromo substituted compounds, 38 and 39 were found to be most effective in targeting ER- $\alpha$. RT-PCR and Western blotting experiments results showed that both the hybrid compounds 38 and 39 altered the mRNA and ER- $\alpha$ receptor protein expression, thus preventing the further transcriptional activation and signaling pathway in cancer cell line (Table 13, Figs. 28 and 29). GlideXP (Glide Extra precision) with vdW scaling 0.8 was used to carry out molecular docking and ranked them based on the GlideXP score. Induced fit simulation was employed to anlayse the binding interaction pattern of both the compounds with receptor ER- $\alpha$ (PDB: 4XI3) and it showed that these derivatives bind in the shallow binding site of the ER- $\alpha$ receptor in similar docking pose as that of the bazedoxifene with strong binding affinity of $-12.51 \mathrm{kcal} / \mathrm{mol}$ and $-12.06 \mathrm{kcal} / \mathrm{mol}$ respectively that is comparable to the bazedoxifene $(-9.33 \mathrm{kcal} /$ mol). These compounds showed H-bond interaction with Asp 351, Leu 346, Asn 532, Val 533, respectively. Compounds 38 and 39 showed extensive van der Waals forces of interaction with various amino acids listed in Table 13.

Perron et al. [38], synthesized two new molecules of $17 \beta$-estradiol-linked platinum (II) complexes by linking alkyl chain at position 16th of the steroid nucleus. The anticancer potential of these prepared derivatives was determined on estrogen dependent and independent (ER+ and ER-) human breast tumor cell lines: MCF-7 and MDA-MB-231. by Sulforhodamine B colorimetric assay. The compound 40, (Fig. 28) showed potent cytotoxicity against both tumor cell line and also displayed high affinity for ER- $\alpha$ as evaluated by HitHunter EFC Estrogen Fluorescence assay kit.

Lappano et al. [39], synthesized indole derivative, compound 41 (Fig. 28) and its anticancer properties were exerted through ER- $\alpha$ and GPER receptor in breast cancer cells as determined by RT-PCR, western blotting assay. The simultaneous antagonistic action exhibited on both GPER and ER- $\alpha$ by 41 showed a new pharmacological approach for targeting breast tumors which express one or both receptors during cancer progression. Docking study carried out with the help of GOLD 5.0.1., program using a genetic algorithm illustrated that compound 41 bind to ER- $\alpha$ in similar manner as OHT as shown in Fig. 30.

Mortensen et al. [40], developed a library of 3-alkyl-2,4,5-triarylfurans derivatives whose selectivity for ER alpha receptor increased due to presence of basic side chain on the 4th position of phenol. From synthesized compounds, the structure activity relationship evaluation of compound 42 (Fig. 28) which was found to be the most active and selective antagonist is shown in (Fig. 31). A dose-response curve for 42 showed that (at concentration $0.1 \mu \mathrm{M}$ ) it wholly suppressed the transcriptional activity of estradiol via ER- $\alpha$, without affecting ER- $\beta$. The $\mathrm{IC}_{50}$ values approximately $6.5 \times 10^{-8}$ and $4.8 \times 10^{-7} \mathrm{M}$ of compound 42 on ER- $\alpha$ and ER- $\beta$ are 
Sharma et al. Chemistry Central Journal

(2018) 12:107

Page 19 of 32

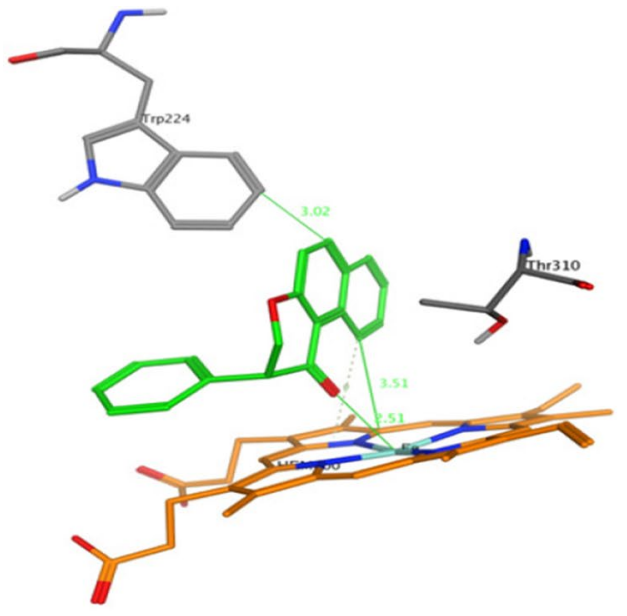

33

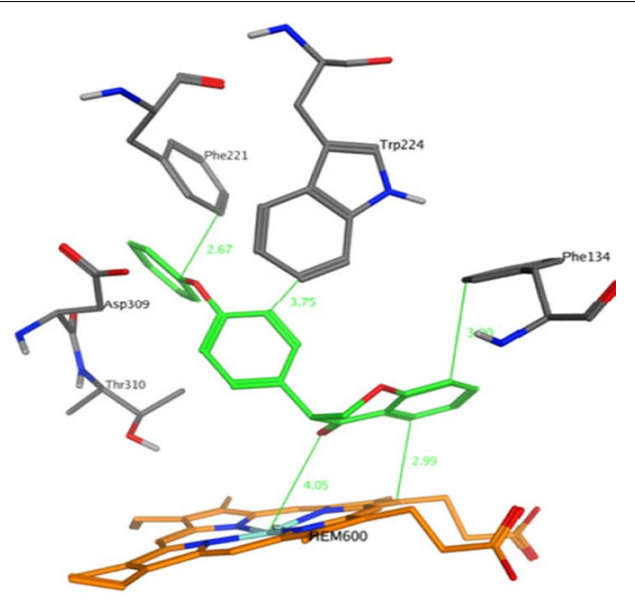

34
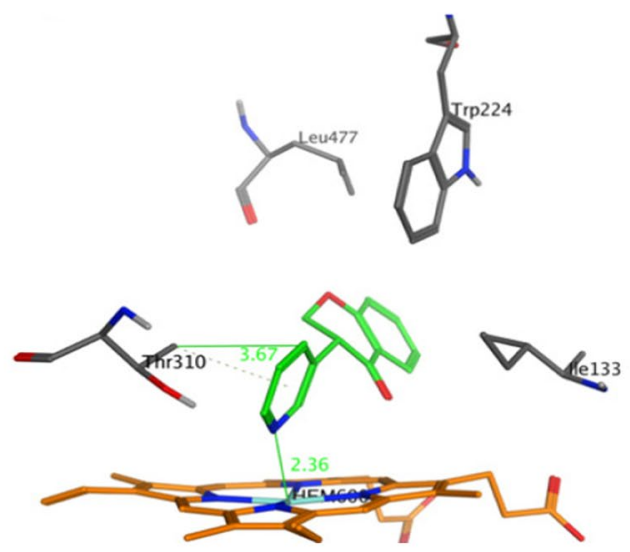

35

Fig. 26 Pictorial presentation of compounds 33-35

Table 12 Anticancer activity and binding affinity of the synthesized derivatives 36-37

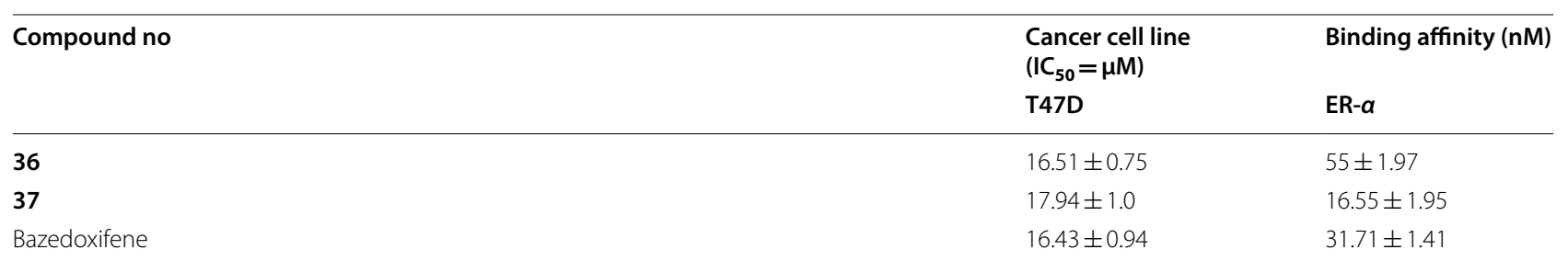

Amino acid residues

Met 343, Met 421, Leu 525, Met 522, Met 388, Leu 428, Ala 350, Leu 391, Leu 387, le 424, Leu 349, Leu 384, Trip 383, Leu 354, Pro 535, Leu 346, Leu 539,

Val534 and Pho 404 


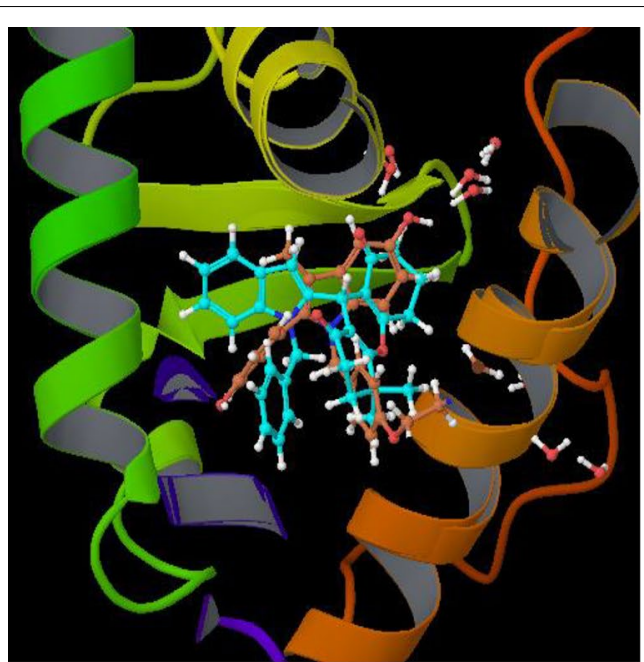

36

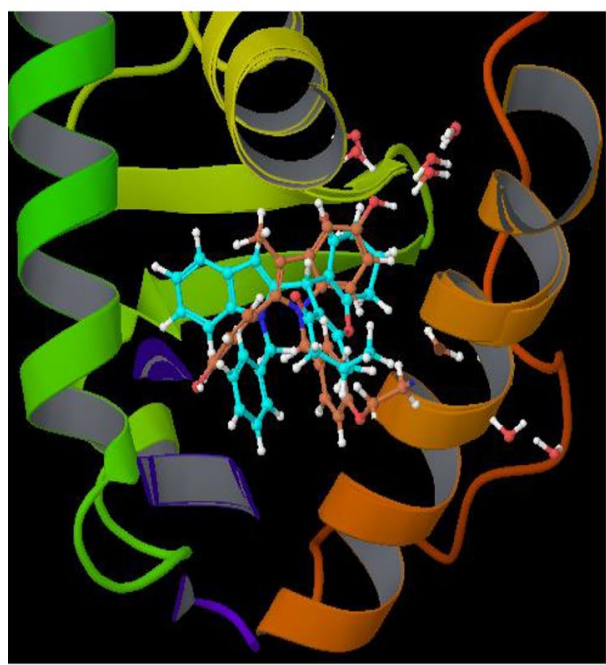

37

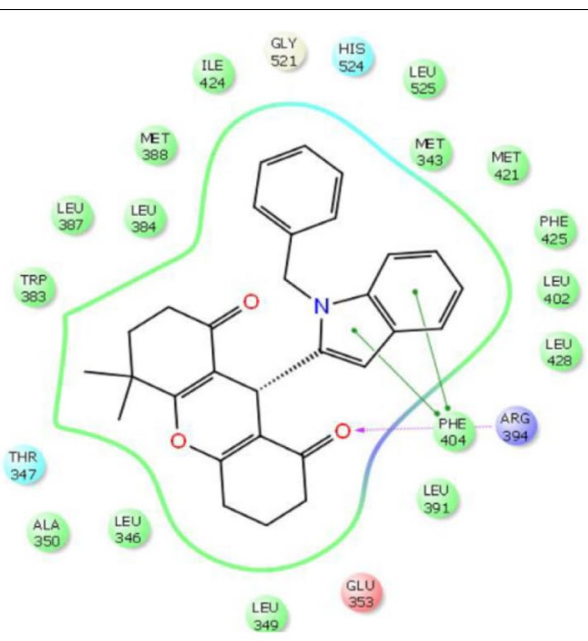

Ligand interaction diagram for 36

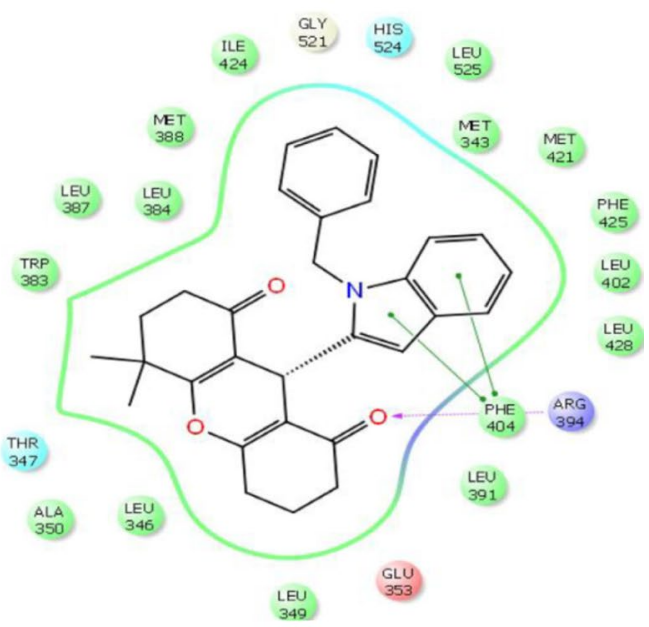

Ligand interaction diagram for 37

Fig. 27 Pictorial presentation of compound $\mathbf{3 6}$ and $\mathbf{3 7}$

Table 13 Anticancer results $\left(\mathrm{IC}_{50}=\mu \mathrm{M}\right)$ of the synthesized derivatives 38-39

\begin{tabular}{lc}
\hline Compound No. & $\begin{array}{l}\text { Cancer cell line } \\
\text { T47D }\end{array}$ \\
\hline $\mathbf{3 8}$ & $15.48 \pm 0.10$ \\
$\mathbf{3 9}$ & $4.99 \pm 0.60$ \\
Amino acid residues & \\
Met343, Thr 347, Glu 385, Leu 354, Met 357 Trp 383, Glu 353, Leu 384, \\
Leu 387, Met 388, Leu 391, Arg 394, Leu 402, Met 421, Leu 349, Ile \\
424, Phe 425, Met 522, Leu 428, Gly 521, His 524, Phe404, Met 517, \\
Leu 525, Met 528, Ser 518, Lys 531Val 534, Pro535, Ser 536, Leu 539, \\
Cys 530, Leu 540 and Ala 350 \\
\hline
\end{tabular}

respectively, indicated tenfold antagonist selectivity for ER- $\alpha$ over ER- $\beta$.

Genistein, a soy isoflavone, has structure analogous to estrogen and can exhibit antiestrogenic activity at high concentration. To make it effective and selective estrogen alpha antagonists at lower concentration, Marik et al. [41], designed and synthesized new genistein scaffolds by introducing stiffer and bulkier side chain that restrain the agonist binding by steric hindrance as evaluated by eHiTS docking program (SymbioSys Inc., Nashua, NH). Among these compounds, compounds 43, 44 and 45 showed antiproliferative activity as evaluated against ER responsive breast cancer cell lines (T47D, 21PT and 
Sharma et al. Chemistry Central Journal

(2018) 12:107

Page 21 of 32

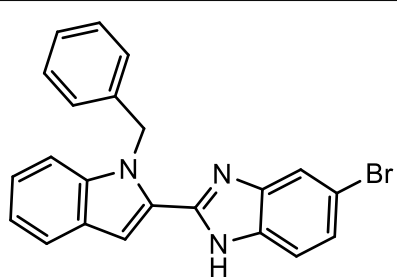

38

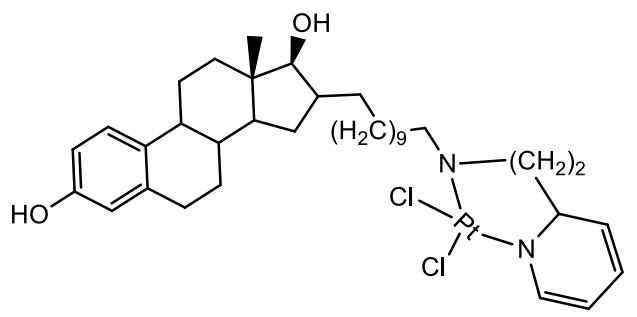

40<smiles>Brc1ccc2[nH]c(-c3cc4ccccc4[nH]3)nc2c1</smiles>

39<smiles>CCOC(=O)/C=C(/C)c1cn(C)c2ccc(O/C(C)=C/COC(=O)CC)cc12</smiles>

41

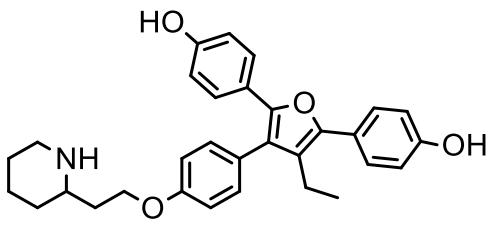

42<smiles>O=c1c(-c2ccc(O)cc2)coc2cc(OCCn3cc(-c4ccccc4)nn3)cc(O)c12</smiles>

44<smiles>O=c1c(-c2ccc(OCCn3cc(-c4ccccc4)nn3)cc2)coc2cc(OCCN3CC(c4ccccc4)N=N3)cc(O)c12</smiles>

43<smiles>CCCCN(C)C(=O)CCCCCCCCCCc1oc2cc(O)cc(O)c2c(=O)c1-c1ccc(O)cc1</smiles>

45<smiles>CCCC(CCC)(c1ccc(O)c(C)c1)c1ccc(C(=O)OCC)[nH]1</smiles>

46

Fig. 28 Molecular structures of compounds (38-46) 


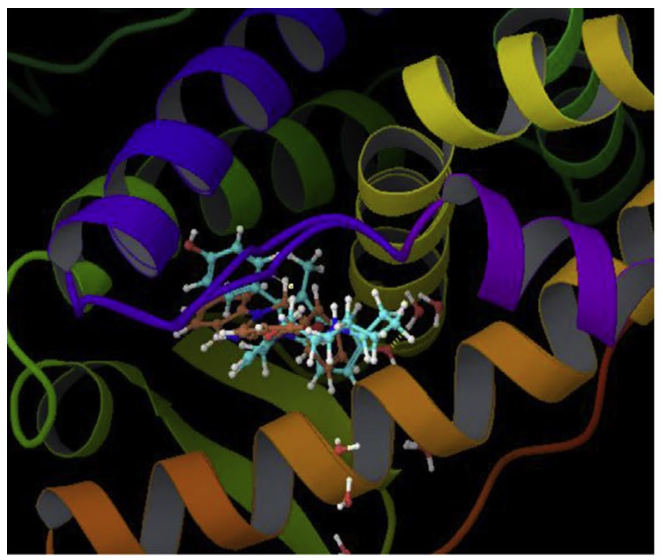

38

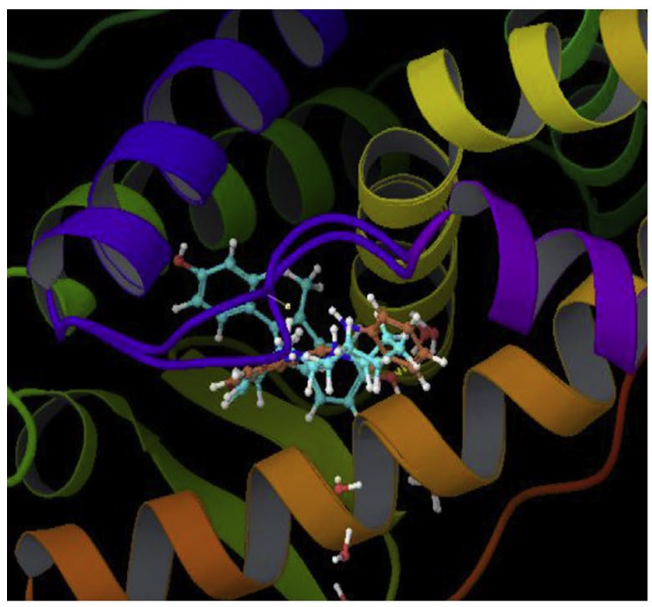

39

Fig. 29 Pictorial presentation of compound $\mathbf{3 8}$ and $\mathbf{3 9}$

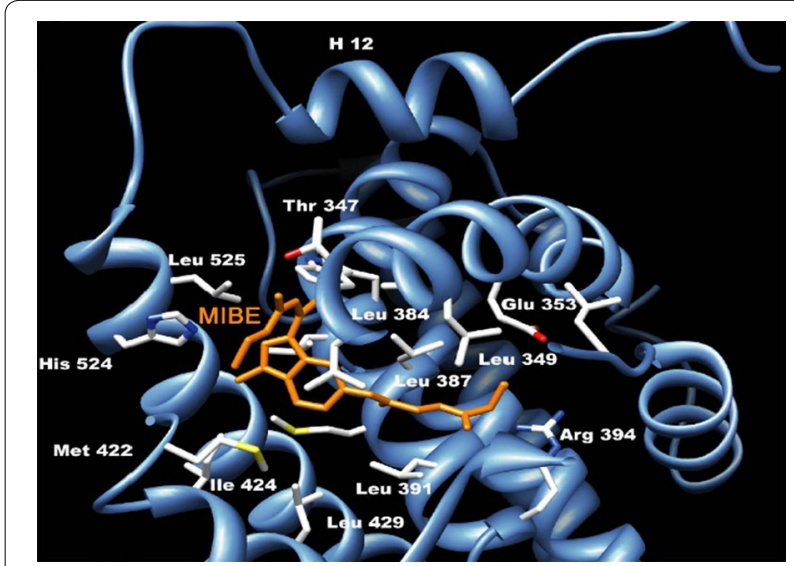

Fig. 30 Pictorial presentation of compound $\mathbf{4 1}$

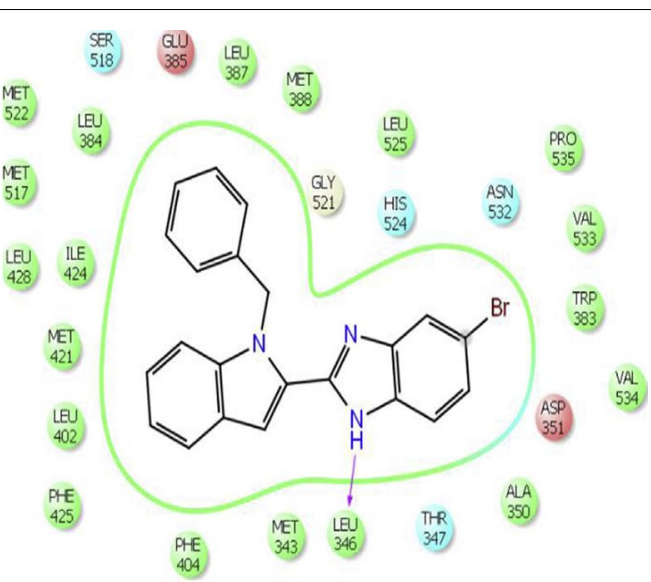

Ligand interaction diagram for 38

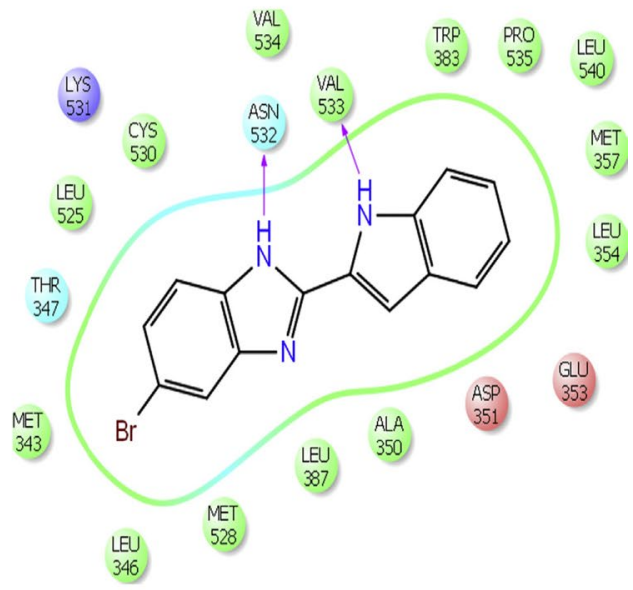

Ligand interaction diagram for 39

MCF-7) by MTT assay (Table 14, Fig. 28). Compounds 43, 44 and 45 exhibited anticancer effect by inhibiting ER $\alpha$ messenger RNA expression.

\section{Diphenylheptane skeleton}

Eto et al. [42], synthesized a novel library of 4-heterocycle-4-phenylheptane analogues and evaluated their estrogen receptor antagonistic activity. Compound 46, [ethyl 5-(4-(4-hydroxy-3-methyl-phenyl)heptan-4-yl)1H-pyrrole-2-carboxylate], (Fig. 28 and SAR Fig. 32)] containing the pyrrole ring displayed the highest binding affinity (195 nM) for ER alpha as observed by Fluorescence polarization assay and exhibited anticancer potenial by suppression of ER alpha transcriptional activity having $\mathrm{IC}_{50}$ value of $450 \mathrm{nM}$. It was observed that the amine of pyrrole ring form $\mathrm{H}$-bond with the 


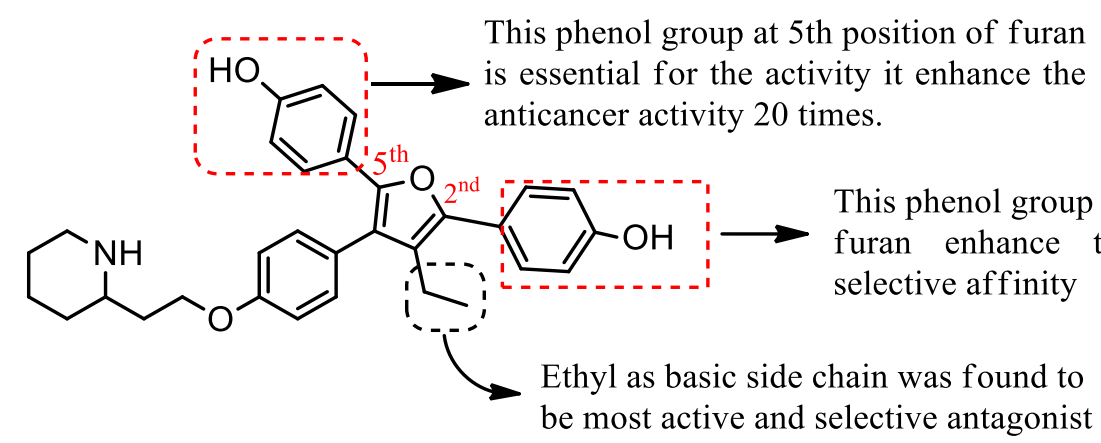

Fig. 31 Structure activity relationship study of compound $\mathbf{4 2}$

Table 14 Cytotoxicity of genistein derivatives 43-45

\begin{tabular}{llcc}
\hline Compound No. & \multicolumn{4}{l}{ Cancer cell lines $\left(\mathbf{I C}_{\mathbf{5 0}}=\boldsymbol{\mu M}\right)$} \\
\cline { 2 - 4 } & MCF-7 & T47D & 21PT \\
\hline $\mathbf{4 3}$ & 1.0 & 1.1 & 2.6 \\
$\mathbf{4 4}$ & 0.8 & 0.9 & 0.9 \\
$\mathbf{4 5}$ & 1.2 & 1.2 & 0.9 \\
Genistein & 14 & 15 & 16.4 \\
\hline
\end{tabular}

vicinal carbonyl group and fixed the orientation of the ethyl ester, resulting in H-bond formation with Thr347 and increases estrogen receptor antagonistic effect.

\section{3, 2'-Dihydroxy-19-norpregna-1, 3, 5(10)-trienes analogs}

Kuznestov et al. [43], prepared a library of ER- $\alpha$ antagonists based on 3,2'-dihydroxy-19 norpregna-1,3,5 (10)-trienes scaffolds and evaluated their cytotoxicity against MCF-7 cell line using MTT assay. 3,2'-Dihydroxy steroids containing the six-membered ring $\mathrm{D}^{\prime}$ was found to be the most effective ER $\alpha$ inhibitors. Compound 47 (Table 15, Fig. 33) was found to be potent one and comparable to that of tamoxifen. The molecular docking study showed that the target compound can bind to estrogen receptor in manner similar to estradiol (Fig. 34).
Suresh et al. [44], synthesized tetrahydroisoquinoline (THIQs) derivatives and determined their cytotoxicity against ER (+) MCF-7 (breast), MDA-MB-231 (breast) and Ishikawa (endometrial) tumor cell lines using CellTiter-Glo luminescent cell viability assay. In this study, compounds 48, 49 and 50 were found to be most active ones compared to tamoxifen (Table 16, Fig. 33). The synthesized compounds were also docked with ER $\alpha$ and ER $\beta$ to find out their favorable bioactive conformations (Figs. 35 and 36)

Jiang et al. [45], designed and synthesized new analogs of estrogen receptor antagonists of $17 \beta$-estradiol (E2) by coupling reactions and determined their antiproliferative potential against breast tumor cells (MCF-7). Among the synthesized analogs, compounds, 51, 52, 53 and 54 (Table 17, Fig. 37) was found to have profound inhibitory activity for ER $\alpha$ transactivation as evaluated by luciferase reporter assay. Computational docking studies conducted

Table 15 Anticancer evaluation of compound 47

\begin{tabular}{ll}
\hline Compound No. & $\begin{array}{l}\text { Cancer } \\
\text { cell line } \\
\left.\text { (IC }_{\mathbf{5 0}}=\mu \mathrm{M}\right) \\
\mathbf{M C F}-\mathbf{7}\end{array}$ \\
\hline $\mathbf{4 7}$ & $6.8 \pm 0.7$ \\
Tamoxifen & $5.3 \pm 0.6$ \\
\hline
\end{tabular}

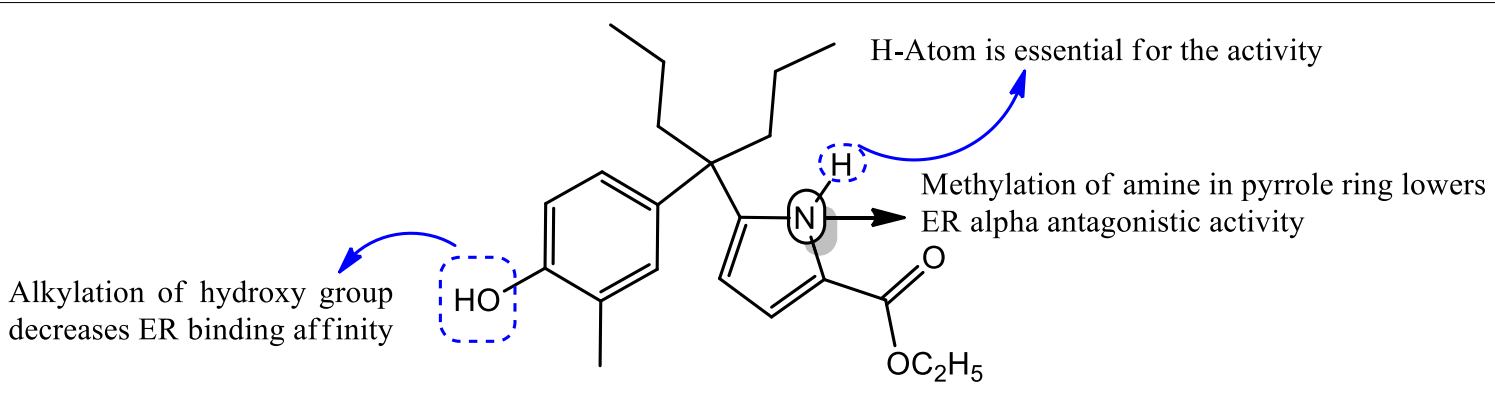

Fig. 32 Structure activity relationship study of compound $\mathbf{4 6}$ 


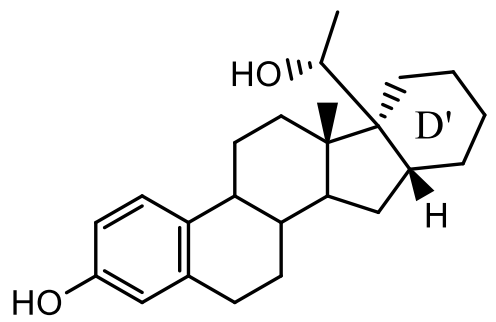

47<smiles>CCc1ccc(C(=O)NN2CCc3cccc(O)c3C2)cc1</smiles>

49<smiles>CCc1ccc(C(=O)NN2CCc3ccc(O)cc3C2)cc1</smiles><smiles>CCc1ccc(C(=O)NN2CCc3ccc(OC)cc3C2)cc1</smiles>

50

Fig. 33 Molecular structures of compounds (47-50)
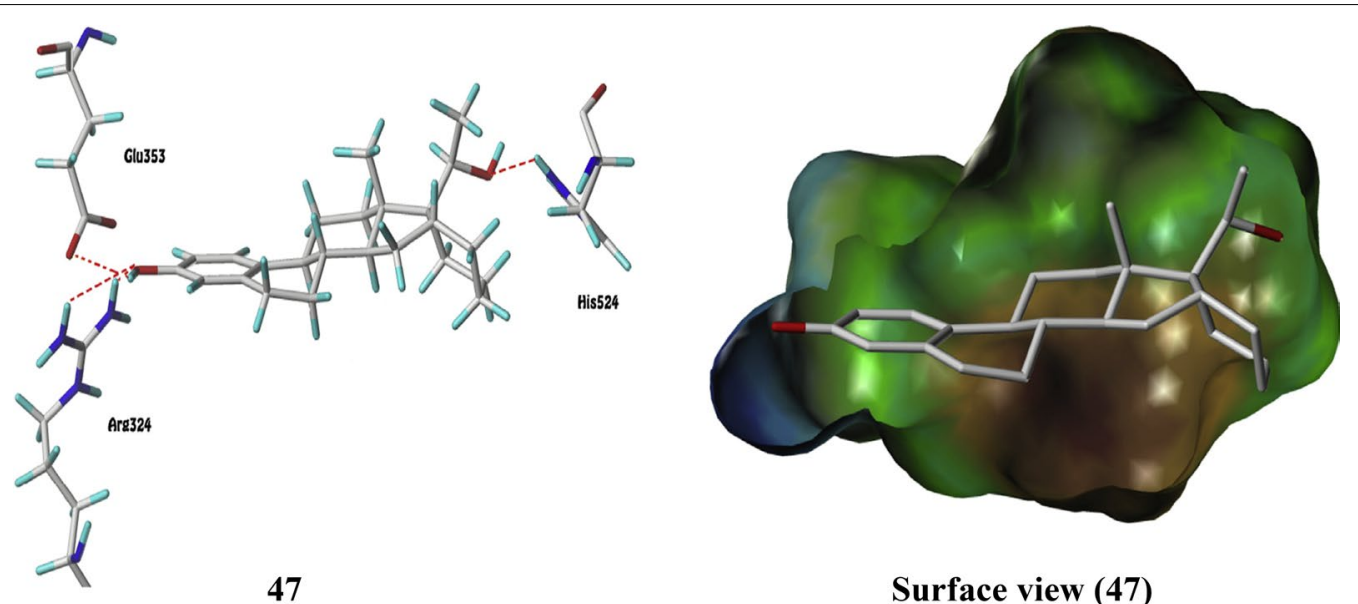

Surface view (47)

Fig. 34 Pictorial presentation and surface view of compound $\mathbf{4 7}$

Table 16 In vitro antiproliferative activity of tetrahydroisoquinoline derivatives 48-50

\begin{tabular}{llll}
\hline Compound No. & \multicolumn{3}{l}{ Tumor cell lines $\left(\mathbf{I C}_{\mathbf{5 0}}=\boldsymbol{\mu g} / \mathbf{m l}\right)$} \\
\cline { 2 - 4 } & Ishikawa & MCF-7 & MDA-MB-231 \\
\hline $\mathbf{4 8}$ & 0.08 & 0.2 & 0.13 \\
$\mathbf{4 9}$ & 0.09 & 0.61 & 1.36 \\
$\mathbf{5 0}$ & 0.11 & 0.25 & 0.23 \\
Tamoxifen & 7.87 & 3.99 & 7.85 \\
\hline
\end{tabular}

using InsightII modeling software (Version 2005, Accelrys Inc. San Diego, CA) also supported their binding with ER $\alpha$ in a manner similar to raloxifene.

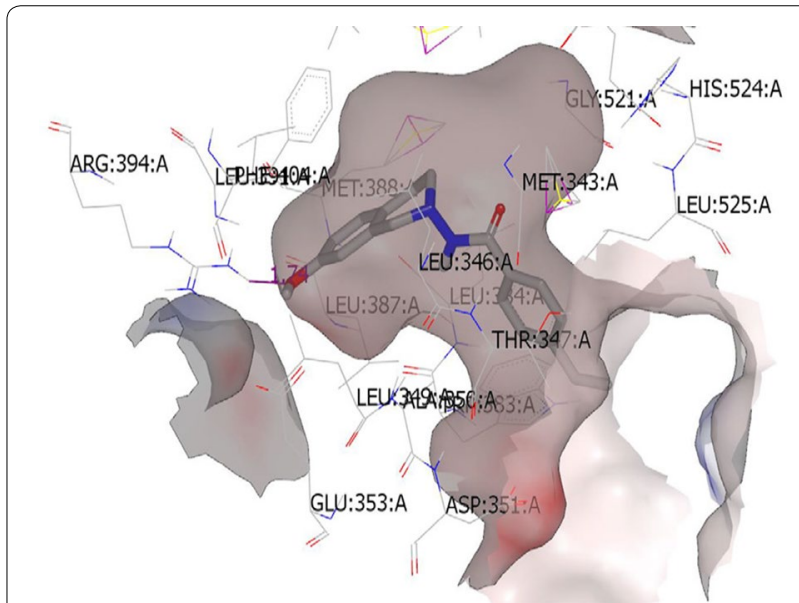

Fig. 35 Top scoring binding pose of the most active substituted THIQ analogs at the active site of ERa-4-OHT complex (3ERT) 


\begin{tabular}{l} 
Ethyl group at this position give \\
promising anticancer activity \\
Fig. $\mathbf{3 6}$ Strcuture activity relationship study of compound $\mathbf{3 6}$ \\
Table $\mathbf{1 7}$ Anticancer activity \\
compounds $\mathbf{5 1 - 5 4}$ \\
\hline Compound No. \\
\hline $\mathbf{5 1}$ \\
$\mathbf{5 2}$ \\
$\mathbf{5 3}$ \\
Tamoxifen \\
Fulvestrant
\end{tabular}

SAR: The structure activity relationship study presented that compounds having two nearly-placed rings and the presence of oxygen and nitrogen atoms in the side chain of estradiol ring were essential for the antagonistic activity.

Ohta et al. [46], designed and prepared estrogen receptor antagonists by doing structural modifications in the diphenylamine estrogen agonist structure by introducing a basic alkylamino side chain at one of the phenol groups. Among evaluated compounds, compound bearing cyclic alkylamine chain showed potent estrogen receptor antagonistic activity than the respective acyclic derivatives as evaluated by cell proliferation assay using MCF-7 cancer cell line. Compound 55, [4-(hexyl(4-(2-(piperidin1-yl)ethoxy)phenyl) amino)phenol], (Fig. 37)] showed the higher antiestrogenic activity $\left(\mathrm{IC}_{50}=1.3 \times 10^{-7} \mathrm{M}\right)$, being 10 folds potent than standard drug (tamoxifen). The alkylamino chains in diphenylamine derivatives played vital job in the exhibition of anticancer activity by means of $\mathrm{H}$-bond formation with Asp351 of the ER $\alpha$. The phenolic hydroxyl group present in compound $\mathbf{5 5}$ interacted strongly with Arg394 and Glu353 group of amino acids of the estrogen receptor $\alpha$ to exhibit its antiproliferative activity.

Lao et al. [47], developed a class of $11 \alpha$-substituted 2-methoxyestradiol analogs. Anticancer activity of these analogs was determined against ER dependent breast cancer cell line targeting ER- $\alpha$ by MTT assay. The anticancer results displayed that compounds $\mathbf{5 6}$ $\left(\mathrm{IC}_{50}=2.73 \mathrm{mM}\right)$ and $57\left(\mathrm{IC}_{50}=7.75 \mathrm{mM}\right)$ (Fig. 38) exhibited good anticancer activity by inducing G2/M cell cycle arrest by disrupting normal microtubule functions.

Marinero et al. [48], prepared a library of organometallic scaffolds having side chains of various lengths 
Sharma et al. Chemistry Central Journal

(2018) 12:107

Page 26 of 32<smiles>C[C@H]1Cc2cc(O)ccc2C2CC[C@@]3(C)C(CC[C@@H](O)C3CCCCC#Cc3ccc(-c4ccno4)cc3)C21</smiles>

51<smiles></smiles>

53

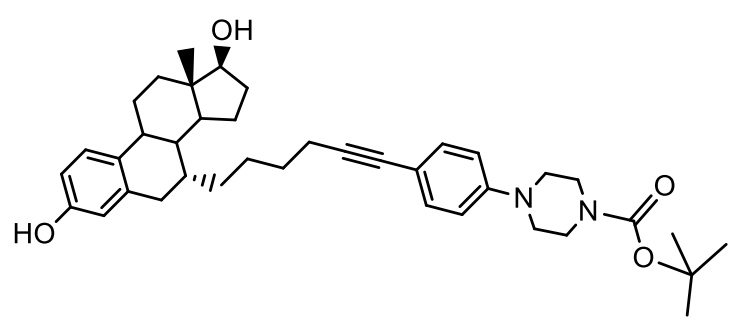

52<smiles>CC1(C)[C@H](O)CCC2C3C(CC[C@@]21C)c1ccc(O)cc1C[C@@H]3O</smiles>

54<smiles>CCCCCCN(c1ccc(O)cc1)c1ccc(OCCN2CCCCC2)cc1</smiles>

55

Fig. 37 Molecular structures of compounds (51-55)<smiles>COc1cc2c(cc1OC)C1C(OC(=O)c3ccc(NC(=O)CN4CCN(C)CC4)cc3)C[C@]3(C)C(OC)CCC3C1CC2</smiles><smiles>COCOc1ccc2c(c1)CCC1C2C2C1C(OC(=O)c1ccc(NC(=O)CN3CCN(C)CC3)cc1)C[C@]1(C)C(OC)CCC21</smiles>

56

57

Fig. 38 Molecular structures of compounds (56-57) 


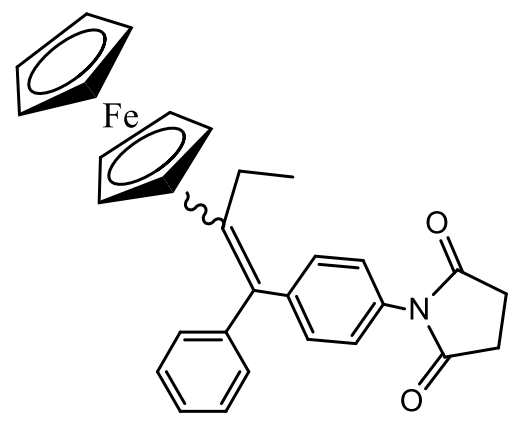

58

Fig. 39 Molecular structure of compound (58)

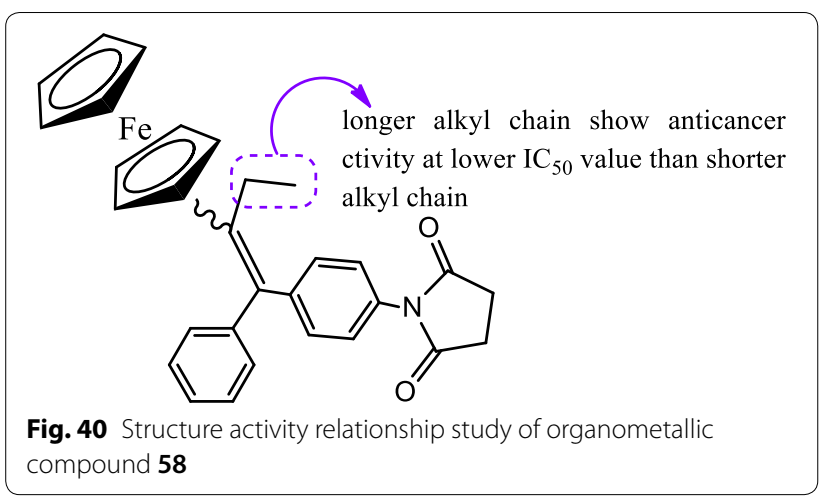

and functional groups. These developed derivatives were screened against hormone dependent MCF-7 breast cancer cells. Anticancer results displayed that compound 58 (Fig. 39) was found to be potent one $\left(\mathrm{IC}_{50}=1.06 \mu \mathrm{M}\right)$ against MCF-7 carcinoma cells, exhibited its antagonist effect through estrogen receptor alpha. The good antiproliferative activity displayed by compound 58 against MCF-7 cells was found to be due to steric effect exerted by the succinimide group and its potential ability to bind with Trp-383, Thr-347 and Ala350 amino acids (Fig. 40).

\section{Conclusion}

As estrogens are well known to play vital role in breast cancer development, considerable research efforts have been done to block their progression. In this article, we reviewed various classes of compounds that can be act as promising lead for future development of novel antibreast cancer agents. Since estrogen receptor $\alpha$ is mainly responsible for the breast cancer initiation and progression, therefore there is need of promising strategies for the design and synthesis of new therapeutic ligands which selectively bind to estrogen alpha receptor and inhibit estrogen dependent proliferative activity. Condensed information of the discussed compounds is given in Table 18. 


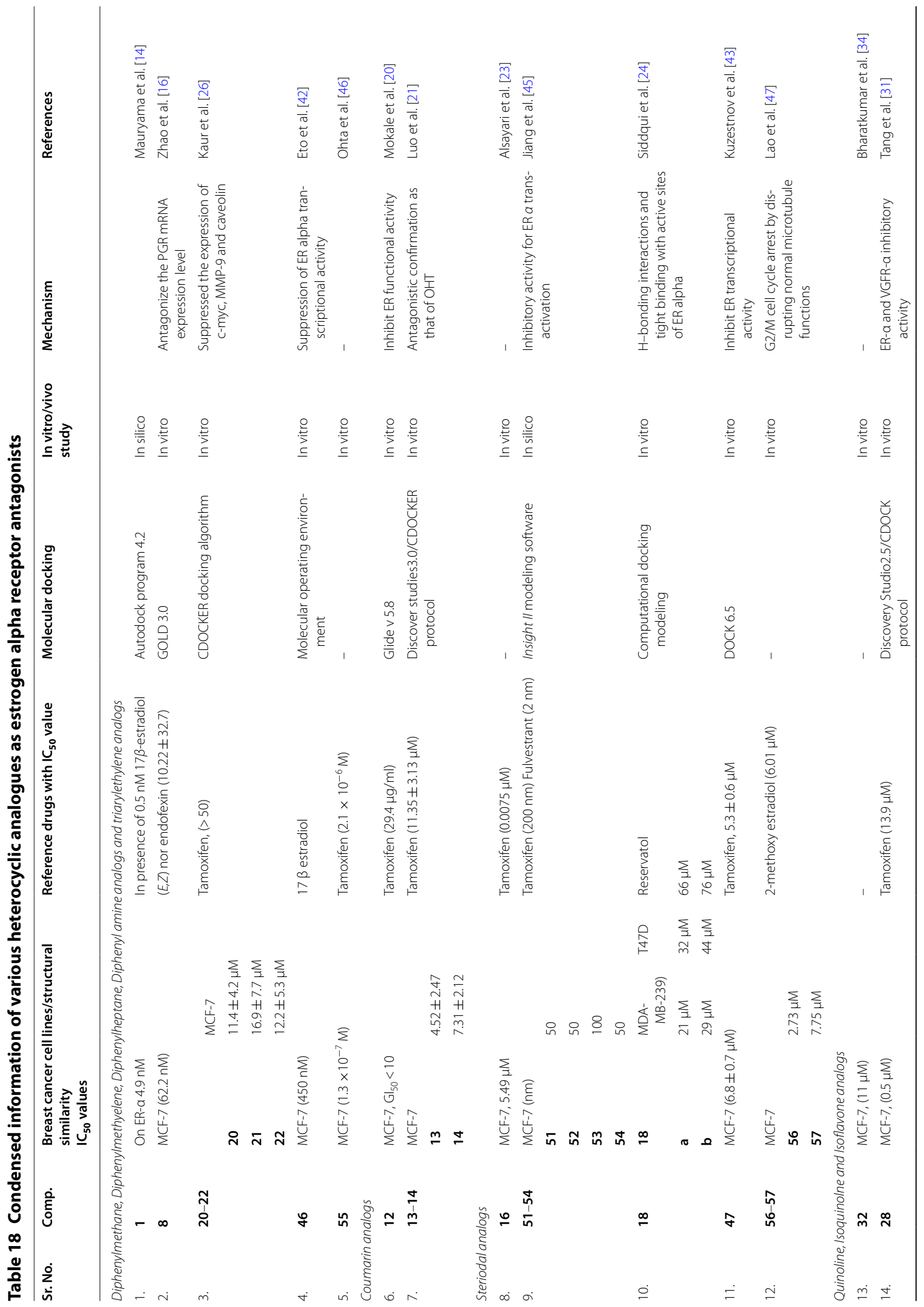




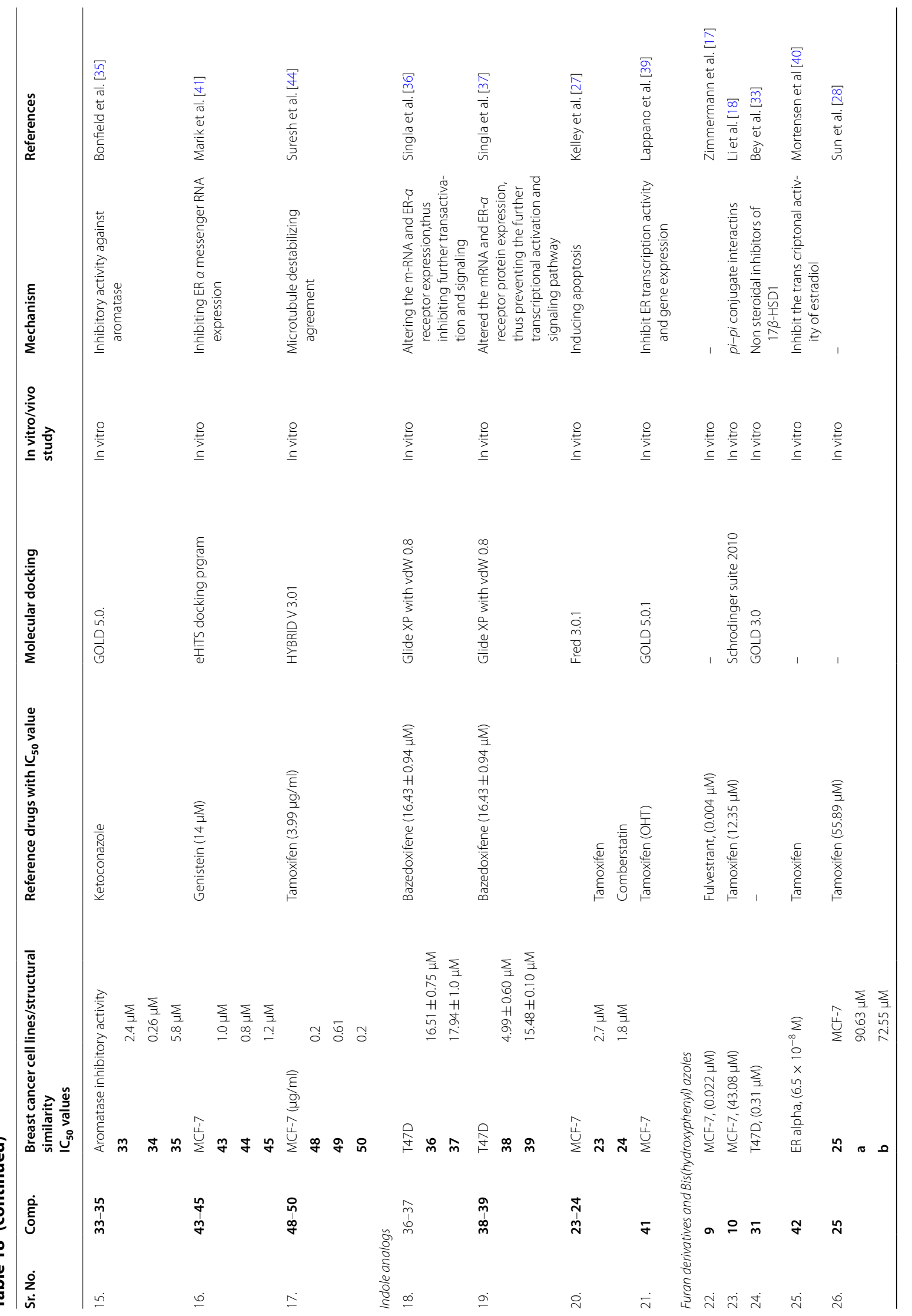




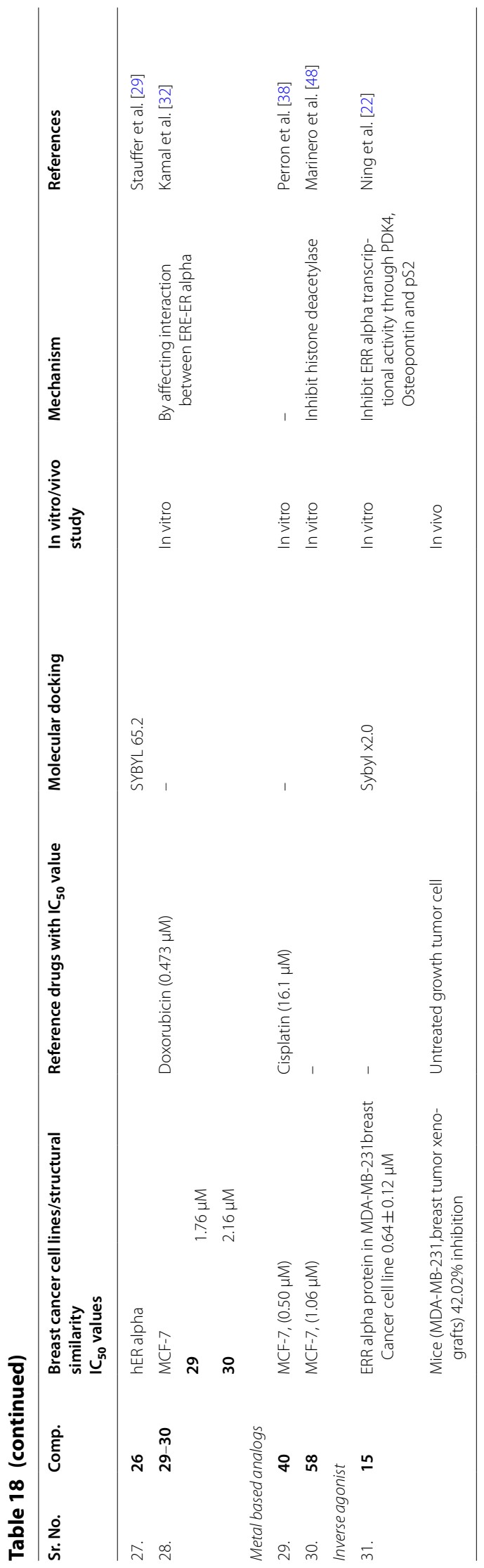




\section{Authors' contributions}

Authors BN, DS and SK have designed and prepared the manuscript. All authors read and approved the final manuscript.

\section{Competing interests}

The authors declare that they have no competing interests.

\section{Availability of data and materials}

Present in manuscript.

\section{Funding}

Not applicable.

\section{Publisher's Note}

Springer Nature remains neutral with regard to jurisdictional claims in published maps and institutional affiliations.

Received: 26 July 2018 Accepted: 5 October 2018

Published online: 25 October 2018

\section{References}

1. American Cancer Society (2017) Breast cancer facts \& figures 2017-2018. American Cancer Society, Atlanta, pp 3-4

2. Althuis MD, Dozier JM, Anderson WF, Devesa SS, Brinton LA (2005) Global trends in breast cancer incidence and mortality 1973-1997. Int J Epidemiol 34:405-412

3. Lukong KE (2017) Understanding breast cancer — the long and winding road. BBA Clin 7:64-77

4. Fan L, Goss PE, Weippl KS (2015) Current status and future projections of breast cancer in Asia. Breast Care 10:372-378

5. Varughese J, Richman S (2010) Cancer care inequity for women in resource-poor countries. Rev Obstet Gynecol 3:122-132

6. Ghoncheh M, Pournamdar Z, Salehiniya H (2016) Incidence and mortality and epidemiology of breast cancer in the world. Asian Pac J Cancer Prev $17: 43-46$

7. Saha Roy S, Vadlamudi RK (2011) Role of estrogen receptor signaling in breast Cancer metastasis. Int J Breast Cancer 2012:1-8

8. Ali S, Rasool M, Chaoudhay H, Pushparaj PN, Jha P, Hafiz A, Mahfooz M, Sami GA, Kamal MA, Bashir S, Ali A, Jamal MS (2016) Molecular mechanisms and mode of tamoxifen resistance in breast cancer. Bioinformation 12(3):135-139

9. Osborne CK, Wakeling A, Nicholson RI (2004) Fulvestrant: an oestrogen receptor antagonist with a novel mechanism of action. $\mathrm{Br} J$ Cancer 90:S2-S6

10. Paterni I, Granchi C, Katzenellenbogen JA, Minu F (2014) Estrogen receptors alpha (ER $a$ ) and beta (ER $\beta$ ): subtype-selective ligands and clinical potential. Steroids 90:13-29

11. Mukherjee S, Majumder D (2009) Computational molecular docking assessment of hormone receptor adjuvant drugs: breast cancer as an example. Pathophysiology 16:19-29

12. Pavlin M, Spinello A, Pennati M, Zaffaroni N, Gobbi S, Bisi A, Colombo G, Magistrato A (2018) A computational assay of estrogen receptor a antagonists reveals the key common structural traits of drugs effectively fighting refractory breast cancers. Sci Rep 8(649):1-11

13. Ansari MI, Hussain MK, Arun A, Chakravarti B, Konwar R, Hajela K (2015) Synthesis of targeted dibenzo[b, $f]$ thiepines and dibenzo[b, $f]$ oxepines as potential lead molecules with promising anti-breast cancer activity. Eur J Med Chem 99:113-124

14. Maruyama K, Nakamura M, Tomoshige S, Sugita K, Makishima M, Hashimoto Y, Ishikawa M (2013) Structure-activity relationships of bisphenol A analogs at estrogen receptors (ERs): discovery of an ER a-selective antagonist. Bioorg Med Chem Lett 23:4031-4036

15. Parveen I, Ahmed N, Idrees D, Khan P, Hassan MI (2017) Synthesis, estrogen receptor binding affinity and molecular docking of pyrimidinepiperazine-chromene and quinoline conjugates. Bioorg Med Chem Lett 27(18):4493-4499
16. Zhao LM, Jin HS, Liu J, Skaar TC, Ipe J, LvW, Flockhart DA, Cushman M (2016) A new suzuki synthesis of triphenylethylenes that inhibit aromatase and bind to estrogen receptors $\alpha$ and $\beta$. Bioorgan Med Chem 24:5400-5409

17. Zimmermann J, Liebl R, Angerer EV (2005) 2, 5-Diphenylfuran-based pure antiestrogens with selectivity for the estrogen receptor $a$. J Steroid Biochem Mol Biol 94:57-66

18. Li XY, He BF, Luo HJ, Huang NY, Deng WQ (2013) 3-Acyl-5-hydroxybenzofuran derivatives as potential anti-estrogen breast cancer agents: a combined experimental and theoretical investigation. Bioorg Med Chem Lett 23:4617-4621

19. Kirkiacharian S, Lormier AT, Chidiack H, Bouchoux F, Cerede E (2004) Synthesis and binding affinity to human $\alpha$ and $\beta$ estrogen receptors of various 7-hydroxycoumarins substituted at 4- and 3,4-positions. II Farmaco 59:981-986

20. Mokale SN, Begum A, Sakle NS, Shelke VR, Bhavale SA (2017) Design, synthesis and anticancer screening of 3-(3-(substituted phenyl)acryloyl)$2 \mathrm{H}$-chromen-2ones as selective anti-breast cancer agent. Biomed Pharmacother 89:966-972

21. Luo G, Chen M, Lyu W, Zhao R, Xu Q, You Q, Xiang H (2017) Design, synthesis, biological evaluation and molecular docking studies of novel 3-aryl-4-anilino-2H-chromen-2-one derivatives targeting ER $a$ as antibreast cancer agents. Bioorgan Med Chem Lett 27:2668-2673

22. Ning Y, Chen H, Dua Y, Ling H, Zhang L, Chen L, Qi H, Shi X, Li Q (2017) A novel compound Ling $\mathrm{H} 2-10$ inhibits the growth of triple negative breast cancer cells in vitro and in vivo as a selective inverse agonist of estrogenrelated receptor a. Biomed Pharmacother 93:913-922

23. Alsayari A, Kopel L, Ahmed MS, Pay A, Carlson T, Halaweish FT (2017) Design, synthesis and biological evaluation of steroidal analogs as estrogenic/anti-estrogenic agents. Steriods 118:32-40

24. Siddiqui A, Dandawate P, Rub R, Padhye S, Aphale S, Moghe A, Jagyasi A, Swamy KV, Singh B, Chatterjee A, Ronghe A, Bhat HK (2013) Novel aza-resveratrol analogs: synthesis, characterization and anticancer activity against breast cancer cell lines. Bioorgan Med Chem Lett 23:635-640

25. Ronghe A, Chatterjee A, Singh B, Dandawate P, Abdalla F, Bhat NK, Padhye S, Bhat HK (2016) 4-(E)-\{(p-Tolylimino)-methylbenzene-1,2-diol a novel resveratrol analog, differentially regulates estrogen receptors $a$ and $\beta$ in breast cancer cells. Toxicol Appl Pharmacol 301:1-13

26. Kaur G, Mahajan MP, Pandey MK, Singh P, Ramisetti SR, Sharma AK (2016) Design, synthesis and anti-breast cancer evaluation of new triarylethylene analogs bearing short alkyl- and polar amino-/amido-ethyl chains. Bioorg Med Chem Lett 26:1963-1969

27. Kelly PM, Bright SA, Fayne D, Pollock JK, Zisterer DM, Williams DC, Meegan MJ (2016) Synthesis, antiproliferative and pro-apoptotic activity of 2-phenylindoles. Bioorgan Med Chem 24:4075-4099

28. Sun R, Song J, Liu SJ, Zhao H, Yan CL, Zhang AJ, Koirala D, Li DW, Hu C (2011) Design, synthesis and biological evaluation of 1,4-dihydrothieno $\left[3^{\prime}, 2^{\prime}: 5,6\right]$ thiopyrano $[4,3-c]$ pyrazole-3-carboxylic amide derivatives as potential estrogen receptor antagonists. Chin Chem Lett 22:256-259

29. Stauffer SR, Huang YR, Aron ZD, Coletta CJ, Sun J, Katzenellenbogen BS, Katzenellenbogena JA (2001) Triarylpyrazoles with basic side chains: development of pyrazole-based estrogen receptor antagonists. Bioorgan Med Chem 9:151-161

30. Dandawate P, Khan E, Padhye S, Gaba H, Sinha S, Deshpande J, Swamy KV, Khetmalas M, Ahmad A, Sarkar FH (2012) Synthesis, characterization, molecular docking and cytotoxic activity of novel plumbagin hydrazones against breast cancer cells. Bioorg Med Chem Lett 22:3104-3108

31. Tang Z, Wu C, Wang T, Lao K, Wang Y, Liu L, Muyaba M, Xu P, He C, Luo G, Qian Z, Niu S, Wang L, Wang Y, Xiao H, You Q, Xiang H (2016) Design, synthesis and evaluation of 6 -aryl-indenoisoquinolone derivatives dual targeting ER $a$ and VEGFR-2 as anti-breast cancer agents. Eur J Med Chem 118:328-339

32. Kamal A, Faazil S, Hussaini SMA, Ramaiah MJ, Balakrishna M, Patel N, Pushpavalli SNCVL, Bhadra MP (2016) Synthesis and mechanistic aspects of 2-anilinonicotinyl-pyrazolo[1,5-a]pyrimidine conjugates that regulate cell proliferation in MCF-7cells via estrogen signaling. Bioorgan Med Chem Lett 26:2077-2083

33. Bey E, Oberwinkler SM, Kruchten P, Frotscher M, Werth $R$, Oster A, Algül O, Neugebauer A, Hartmann RW (2008) Design, synthesis and biological evaluation of bis(hydroxyphenyl) azoles as potent and selective non-steroidal inhibitors of $17 \beta$-hydroxysteroid dehydrogenase type 1 
(17 $\beta$-HSD 1) for the treatment of estrogen-dependent diseases. Bioorgan Med Chem 16:6423-6435

34. Bharathkumar H, Mohan CD, Ananda H, Fuchs JE, Li F, Rangappa S, Surender M, Bulusu KC, Girish KS, Sethi G, Bender A, Basappa Rangappa KS (2015) Microwave-assisted synthesis, characterization and cytotoxic studies of novel estrogen receptor a ligands towards human breast cancer cells. Bioorg Med Chem Lett 25:1804-1807

35. Bonfield K, Amato E, Bankemper T, Agard H, Steller J, Keeler JM, Roy D, McCallum A, Paula S, Ma L (2012) Development of a new class of aromatase inhibitors: design, synthesis and inhibitory activity of 3-phenylchroman-4-one (isoflavanone) derivatives. Bioorgan Med Chem 20:2603-2613

36. Singla R, Gupta KB, Upadhyay S, Dhiman M, Jaitak V (2018) Design, synthesis and biological evaluation of novel indole-xanthendione hybrids as selective estrogen receptor modulators. Bioorgan Med Chem 26:266-277

37. Singla R, Gupta KB, Upadhyay S, Dhiman M, Jaitak V (2018) Design, synthesis and biological evaluation of novel indole-benzimidazole hybrids targeting estrogen receptor alpha (ER- $a$ ). Eur J Med Chem 146:206-219

38. Perron V, Rabouina D, Asselina E, Parenta S, Gaudreaultb RC, Berube G (2005) Synthesis of $17 \beta$-estradiol-linked platinum (II) complexes and their cytocidal activity on estrogen-dependent and-independent breast tumor cells. Bioorgan Chem 33:1-15

39. Lappano R, Santolla MF, Pupo M, Sinicropi MS, Caruso A, Rosano C, Maggiolini M (2012) MIBE acts as antagonist ligand of both estrogen receptor $\mathrm{a}$ and GPER in breast cancer cells. Breast Cancer Res 14(R12):1-13

40. Mortensen DS, Rodriguez AL, Sun J, Katzenellenbogen BS, Katzenellenbogena JA (2001) Furans with basic side chains: synthesis and biological evaluation of a novel series of antagonists with selectivity for the estrogen receptor alpha. Bioorg Med Chem Lett 11:2521-2524
41. Marik R, Allu M, Anchoori R, Stearns V, Umbricht CB, Khan S (2011) Potent genistein derivatives as inhibitors of estrogen receptor alpha-positive breast cancer. Cancer Biol Ther 11(10):883-892

42. Eto R, Misawab T, Yachidec TN, Ohokad N, Kuriharae M, Naitod M, Tanakaa M, Demizu Y (2018) Design and synthesis of estrogen receptor ligands with a 4-heterocycle-4-phenylheptane skeleton. Bioorgan Med Chem 26(8):1638-1642

43. Kuznetsov YV, Levina IS, Scherbakov AM, Andreeva OE, Fedyushkina IV, Dmitrenok AS, Shashkov AS, Zavarzin IV (2018) New estrogen receptor antagonists. 3, 2'-dihydroxy-19-norpregna-1,3,5(10)-trienes: synthesis, molecular modeling, and biological evaluation. Eur J Med Chem 143:670-682

44. Suresh VKE, Madhavi G, Bereket M, Nelly M, Knife KR (2017) Synthesis and biological evaluations of ring substituted tetrahydroisoquinolines (THIQs) as anti-breast cancer agents. J Cancer Sci Ther 9(7):528-540

45. Jiang SR, Wang P, Smith CL, Zhu BT (2013) Synthesis of novel estrogen receptor antagonists using metal-catalyzed coupling reactions and characterization of their biological activity. J Med Chem 56(7):2779-2790

46. Ohta K, Chib Y, Kaise A, Endo Y (2015) Structure-activity relationship study of diphenylamine-based estrogen receptor (ER) antagonists. Bioorgan Med Chem 23:861-867

47. Lao K, Wang Y, Chen M, Zhang J, You Q, Xiang H (2017) Design, synthesis and biological evaluation of novel 2-methoxyestradiol analogs as dual selective estrogen receptor modulators (SERMs) and anti-angiogenic agents. Eur J Med Chem 139:390-400

48. Marinero JJC, Top S, Jaouen G (2014) Synthesis and characterization of new ferrocenyl compounds with different alkyl chain lengths and functional groups to target breast cancer cells. J Organomet Chem 751:610-619
Ready to submit your research? Choose BMC and benefit from:

- fast, convenient online submission

- thorough peer review by experienced researchers in your field

- rapid publication on acceptance

- support for research data, including large and complex data types

- gold Open Access which fosters wider collaboration and increased citations

- maximum visibility for your research: over $100 \mathrm{M}$ website views per year

At BMC, research is always in progress.

Learn more biomedcentral.com/submissions 